\title{
The Economic Theory of Regulation after a Decade of Deregulation
}

What HAS COME to be called the economic theory of regulation, or ET, began with an article by George Stigler in $1971 .{ }^{1}$ The most important element of this theory is its integration of the analysis of political behavior with the larger body of economic analysis. Politicians, like the rest of us, are presumed to be self-interested maximizers. This means that interest groups can influence the outcome of the regulatory process by providing financial or other support to politicians or regulators.

Simultaneously with Stigler, Richard Posner provided an important critique, and several years later he gave the theory its grandiose name. The major theoretical development of the ET has been an article by Peltzman in 1976 and one by Gary Becker in $1983 .{ }^{2}$ By conventional measures the theory has been an academic success. In this paper I evaluate that success in light of the changes in regulatory institutions that have occurred since the ET's early development.

I am grateful to Gary Becker and George J. Stigler for their valuable comments. I am also grateful to the Center for the Study of the Economy and State, Graduate School of Business, University of Chicago, for financial support.

1. George J. Stigler, "The Theory of Economic Regulation," Bell Journal of Economics and Management Science, vol. 2 (Spring 1971), pp. 3-21.

2. Richard A. Posner, "Taxation by Regulation," Bell Journal of Economics and Management Science, vol. 2 (Spring 1971), pp. 22-50, and "Theories of Economic Regulation," ibid., vol. 5 (Autumn 1974), pp. 335-58; Sam Peltzman, "Toward a More General Theory of Regulation," Journal of Law and Economics, vol. 19 (August 1976), pp. 211-40; and Gary Becker, "A Theory of Competition among Pressure Groups for Political Influence," Quarterly Journal of Economics, vol. 98 (August 1983), pp. 371-400. 
The most notable changes have meant a reduction or substantial elimination of regulatory constraints whose scope is unprecedented in modern American history. The challenge posed by these changes for the ET seems obvious. One strand in the theory is that the producers' interest in restricting competition dominates the political system. But deregulation was sweeping aside many long-standing legal barriers to competition even as the ink was drying on the theory. Doesn't deregulation then decisively falsify the theory?

One easy answer would be that the deregulation movement was a special case-a one-shot response to the peculiar macroeconomic and political conditions of the late 1970s. That was a time of increased concern about inflation and of disillusion with the efficacy of government intervention generally. It was also a time when most of the ultimately successful legislative initiatives toward deregulation bore fruit. It is hard to treat the conjunction of the rightward shift in the political mood and deregulation as entirely coincidental. But it is also hard to push this, or any, special-purpose explanation too far.

This particular special-purpose explanation has factual problems. For example, the deregulation movement was selective. Many areas of regulation escaped essentially unscathed; others, such as the regulation of labor contracts and health care, even prospered. Because of this selectivity, the plausible role of deregulation in the fight against inflation is largely symbolic. No serious investigation could attribute to deregulation more than a microscopic effect on the overall inflation rate. Also, the timing of the political change is not quite right. The culmination of the rightward shift in American politics and of the inflationary spiral occurred in the same year (1980) that saw the end rather than the beginning of de jure deregulation. ${ }^{3}$

Ultimately, however, I eschew a special-purpose absolution of the ET on methodological grounds. The theory purports to be a general model of the forces affecting regulation; that is, it suggests the common

3. My focus here is on de jure deregulation-that is, the institutional changes which would require new legal initiatives to reverse. The plausible role of arguably exogenous or temporary political shifts would grow if the administration of basically unchanged legal institutions were part of the inquiry. Changes in administration and, consequently, administrators can change the regulatory "output" temporarily. It remains uncertain how many of Reagan's purely administrative initiatives, such as the reduced enforcement of the antitrust laws and of occupational health and safety laws, will survive the Bush administration. Evaluation of those initiatives is therefore premature. 
elements underlying regulatory change. In evaluating the theory, one must weigh the importance of these common elements before considering what might be special about the 1970s.

Seen in this light, if the theory implied that every restriction of competition was permanent, one could easily dispose of the ET as a useful model for the deregulation movement. But that is, I will argue, too simple a characterization of the theory. One complication is that the theory does not speak with one voice on the subject of entry into and exit from regulation. Another is the lack of a satisfactory alternative theory. Not one economist in a hundred practicing in the early 1970s predicted the sweeping changes that were soon to happen. Most believed that, however desirable, events like the demise of the Civil Aeronautics Board (CAB) and the shriveling of the Interstate Commerce Commission (ICC) were unlikely to occur soon. This was hardly the first or last forecasting failure in economics, and the methodological pitfalls of evaluating theory by forecasting ability are well known. Nevertheless, the fact that deregulation was such a surprise partly reflects, I will argue, some general problems in the theory of regulatory entry and exit. I will also argue that no version of that theory, including the ET's, is sufficiently well developed to generate sharp predictions about where and when entry or exit will occur.

It is possible, nevertheless, to take advantage of the hindsight afforded by the experience of the past decade in order to evaluate the ET. Though the ET is not a full-blown theory of institutional change, it does suggest circumstances under which such change is more or less likely to occur. Accordingly, one may ask whether the circumstances surrounding the changes of the last decade are broadly consistent or inconsistent with those emphasized by the ET. This is the procedure I follow. To see the underlying motivation, consider entry and exit theory in the more familiar context of ordinary markets. The theory says distressingly little about the speed or timing of entry or exit. But one would recognize a serious shortcoming of the theory if, for example, it frequently took a long time for entry to respond to profits. And it would be hard to take the theory seriously at all if new firms usually entered in the wake of losses and exit followed profits. Here I will ask, in effect, if the ET's version of 'losses" in the political market had any plausible connection to the deregulation that took place. Perhaps unsurprisingly, my overall answer is positive. But the exit-follows-profits phenomenon is not entirely absent. 
In the first section of the paper I summarize the development of the ET and the historical background in which it occurred. I then discuss the shortcomings of the ET as a theory of entry. Finally, I review some of the important changes in regulation that occurred after the theory was developed and evaluate each of them against the relevant elements of the theory.

\section{The Economic Theory in Historical Perspective}

The ET made its debut in 1971 after a decade of unusual ferment in the economic analysis of regulation. Until the early 1960s the prevailing theory of regulation was what Joskow and Noll have called the "normative analysis as a positive theory" (or NPT) ${ }^{4}$ This theory, which has been around in one form or another since Adam Smith, regarded market failure as the motivating reason for the entry of regulation. Once established, regulatory bodies were supposed to lessen or eliminate the inefficiencies engendered by the market failure. The ingenuity of economists ensures that the list of potential sources of market failure will never be complete. But in the early 1960s the most popular culprit was natural monopoly followed at a distance by externalities.

The main problem with the NPT was that until the 1960s it was not systematically tested. To be sure, some economists had expressed dissatisfaction with its predictions in such industries as truck and air transportation where the natural-monopoly rationale for entry and rate regulation did not seem readily applicable. ${ }^{5}$ But these were exceptions to a general belief that most regulatory activity was compressing the gap between price and marginal cost that would otherwise exist. Perhaps the first formal test of that belief was, appropriately enough, Stigler and Friedland's analysis in 1962 of the effects of regulation of electricity rates. ${ }^{6}$ At the time, nothing seemed more settled in the economics of

4. Paul L. Joskow and Roger G. Noll, "Regulation in Theory and Practice: An Overview,"' in Gary Fromm, ed., Studies in Public Regulation (MIT Press, 1981), pp. $1-65$.

5. See, for example, John R. Meyer and others, The Economics of Competition in the Transportation Industries (Harvard University Press, 1959); and Richard E. Caves, Air Transport and Its Regulators: An Industry Study (Harvard University Press, 1962).

6. George J. Stigler and Claire Friedland, "What Can Regulators Regulate? The Case of Electricity," Journal of Law and Economics, vol. 5 (October 1962), pp. 1-16. 
regulation than the presumptive effects of such regulation. Surely restricting entry and imposing maximum rates in this quintessence of a natural monopoly would make rates lower than otherwise. The authors concluded, however, that regulation had not resulted in lower electricity rates.

The importance of the Stigler-Friedland article lies less in this particular result than in its catalytic role. It stimulated an ongoing empirical literature on the effects of regulation. The seeds of the ET were planted by the pattern of results emerging from the first decade of that literature.

That pattern was uncongenial to the NPT. Indeed, it suggested a synthesis that was the exact opposite of the NPT. In 1972 William Jordan provided a good summary of this new synthesis, sometimes called the capture theory of regulation, or CT. ${ }^{7}$ After surveying the extant literature on the effects of regulation, he concluded that Stigler and Friedland's finding of ineffective regulation did not hold for all forms of regulation. But the available examples in which regulation did affect prices shared striking similarities. All were found in naturally competitive or nonmonopolistic industries like surface and air transportation, and in all these instances the effects of regulation were to raise prices and reduce the number of competitors. By contrast, regulation did not change prices in natural monopoly industries, where, Jordan argued, the NPT led us to expect that regulation would have suppressed monopoly power. Thus the correct generalization seemed to be the CT-that regulation served the producer interest either by creating cartels where they would otherwise not exist or by failing to suppress monopoly.

\section{Stigler}

The capture theory was not new by the early 1970s. Well-known versions had appeared earlier. ${ }^{8}$ What was new was its broad appeal to economists based on the accumulating evidence of empirical research within their discipline. However, this new version of the CT shared a conceptual problem with the NPT. Both were empirical generalizations

7. William A. Jordan, "Producer Protection, Prior Market Structure and the Effects of Government Regulation," Journal of Law and Economics, vol. 15 (April 1972), pp. 151-76.

8. For example, Marver H. Bernstein, Regulating Business by Independent Commission (Princeton University Press, 1955). 
without a theoretical foundation. Neither had a ready answer to the question "why should regulation be expected to encourage or suppress monopoly?" Stigler's version of the ET sought to fill that theoretical lacuna. ${ }^{9}$ The specific conclusions Stigler reached bear the imprint of the then accumulating evidence in favor of some form of the CT. Indeed, his article comes across as an effort to rationalize those results. And Stigler had important predecessors. The notion that ordinary voters are "rationally ignorant," which is associated with Anthony Downs, and the free-rider obstacle to collective action, which appears in Olson, are prominent features of Stigler's theory.$^{10}$ But as with the Stigler-Friedland article, the lasting significance of Stigler's 1971 article is less in its specific conclusions or elements than in the question it poses-the why of regulatory behavior-and in the structure of its answer.

As mentioned earlier, in Stigler's formulation political actors are presumed to be self-interested maximizers. Just what is in their objective function is not completely spelled out, but surely it includes securing and maintaining political power. For clarity and simplicity, Stigler ignores both the fact that regulators are usually agents of an executive or legislature rather than agents of voters and the many problems of stability and existence of equilibrium in political modeling. He assumes that regulators do the bidding of a representative politician who has the ultimate power to set prices, the number of firms, and so on. ${ }^{11}$

Stigler's next step is to specify the concrete objects of choice in this politician's utility function. These come down to two-votes and money. That is, one consequence of a regulatory decision is that members of groups affected by the decision will be moved to vote for or against the

9. "Theory of Economic Regulation."

10. Anthony Downs, An Economic Theory of Democracy (Harper, 1957); and Mancur Olson, The Logic of Collective Action: Public Goods and the Theory of Groups (Harvard University Press, 1965).

11. In a recent attempt to extend the ET by filling in some of the missing institutional structure, Weingast and Moran argue that, at the federal level, congressional oversight committees are the crucial intermediary between the regulatory agency on the one hand and the congressmen and their constituents on the other. They show that policy changes by the Federal Trade Commission were related to changes in the policy preferences of the oversight committee. This evidence, according to the authors, is inconsistent with the view that agencies are essentially unconstrained by legislatures and thus can pursue their own policy agenda. Barry R. Weingast and Mark J. Moran, "Bureaucratic Discretion or Congressional Control? Regulatory Policymaking by the Federal Trade Commission," Journal of Political Economy, vol. 91 (October 1983), pp. 765-800. 
representative politician. Because his ultimate goal is securing and enhancing his power, the politician prefers decisions that directly elicit favorable votes. Regulatory decisions can also elicit campaign contributions, contributions of time to get-out-the-vote, occasional bribes, or well-paid jobs in the political afterlife. Because the more well-financed and well-staffed campaigns tend to be the more successful and because a self-interested politican also values wealth, he will pay attention to these resource (money) consequences of regulatory decision as well as to the direct electoral consequences. Accordingly, groups that may themselves be too small to offer many votes directly in support of a regulatory policy can nevertheless affect that policy by delivering other valuable resources. This notion is another durable feature of the ET literature.

Another durable aspect of Stigler's contribution is his emphasis, already implicit in the preceding, on the distributional aspects of regulatory decisions. Self-interested politicians and constituents exchange objects of utility - a price or entry certificate for votes and money-and what matters to each actor is their wealth or utility, not the aggregate social wealth. Aggregate welfare does matter, in the sense that slices of a pie tend to be larger if the pie is larger. But Stigler's criticism of the NPT is simply that aggregate welfare as such is not what a politician plausibly maximizes.

The results of any analysis of utility-maximizing behavior usually hinge more critically on its specification of the constraint than on the objective function. This is true for Stigler. Though he makes no formal analysis of a constrained maximization problem, one clearly emerges from the discussion. If regulators bestow benefits in exchange for votes and money, the latter must be delivered. (Whether this is done before or after a regulatory decision is one of those suppressed details of the machinery of politics.) Because the benefits typically accrue to groups rather than individuals, the technology for delivery entails group organization. Stigler's results follow more or less directly from his specification of this technology.

Stigler emphasizes two related kinds of costs that constrain a group's ability to deliver votes and money: information and organization costs. Groups must organize to lobby and to deliver campaign contributions, and their members must know enough to vote "right" on election day. Because knowledge and organization consume resources, low-cost 
groups tend to be favored at the expense of high-cost groups. And more important, if, as is typical in regulatory issues, the relevant groups are of widely different size, the numerically larger group will tend to be the loser. To see why, consider a decision on how high or low a price should be set or on how many firms should be allowed in. In the relevant range, having more firms and lower prices benefits buyers and harms sellers. Though Stigler alludes to complexities, such as the potentially disparate interests of subgroups, the main issue is whether the buyers or the sellers win a more-or-less fixed prize. Since the number of buyers is usually manyfold greater than the number of sellers, the buyers will probably face prohibitively high costs of organization. The number of collections required and the incentives to free riding will ensure this. Moreover, because each buyer's stake in the outcome is trivial compared with that of the typical seller, it is unlikely that all buyers will know enough to reciprocate any benefits (or punish costs) at the polls unless considerable resources are spent on educating them. The larger per capita stakes yield a saving of information costs to the smaller group (consider the odds that a typical taxpayer knows more about the National Science Foundation's budget than a typical economist), and their smaller numbers make for lower organization cost. Thus the main conclusion of Stigler's analysis is that the producer interest will win the bidding for the services of a regulatory agency. More generally, in any similar political contest between groups of disparate size, the compact organized interest (say, farmers in a developed economy) will usually win at the expense of the diffuse group (taxpayers).

The general framework developed by Stigler, with its emphasis on self-interested political behavior and the importance of organization and information costs, became a hallmark of the subsequent ET literature. But it quickly became apparent that the generalization that regulation served the producer interest had moved too far from the NPT. Indeed, in the same issue of the Bell Journal in which Stigler's article appeared, his colleague Richard Posner demonstrated some of the infirmities of the $\mathrm{CT}$ as empirical generalization. ${ }^{12} \mathrm{He}$ did so by emphasizing the phenomenon of "internal subsidization" (sometimes called cross subsidization), the enforced provision of service to selected consumer groups at especially low, often below-cost, prices. Those consumers are "subsidized", out of potential producer rents generated elsewhere in the regulated

12. "Taxation by Regulation." 
industry. Posner's argument was that cross subsidies are so pervasive and important that no fig-leaf modification of the CT can cover them. Consider just one of many examples offered by Posner: the pre-Amtrak perpetuation of railroad passenger service by the ICC. In CT revisionism, the ICC's raison d'être is to cartelize surface transportation. But how can such devotion to the producer interest be reconciled with the preservation of money-losing passenger service? The simple answer, repeated for many other examples, is that it cannot. The losses were too great and the efforts of the railroads to escape them were too strenuous for any CT explanation to be plausible.

Posner's discussion of cross subsidies illustrates a more general point. Viewed from afar, a particular type of regulation often seems to fit the CT or NPT mold. But a closer look usually uncovers too many exceptions for this dichotomy to be plausible. Consider, for example, areas of regulation like antitrust or health-safety-environmental regulation. If these had been put to the vote in a two-theory election, most economists would have voted for the NPT even after the ascendancy of the CT. But when economists analyze these modes of regulation more closely, they turn up at least as many exceptions to the NPT as confirmations and even a healthy dose of CT-like results. ${ }^{13}$

\section{Peltzman}

The notion that no single economic interest captures a regulatory body plays a prominent role in the 1976 article by Peltzman. ${ }^{14} \mathrm{He}$ derives an equilibrium in which the utility-maximizing politician allocates benefits across groups optimally - that is, in accord with the usual marginal conditions. Thus as long as some consumers can offer some votes or money for a small departure from the cartel equilibrium, pure producer protection will not, in general, be the dominant political strategy. Two factors work against such a solution. First, the organization and information costs emphasized by Stigler make it unlikely that the producers will withdraw all their support for the regulatory system for a small

13. Most economists, for example, favor increased use of taxes and tradable pollution rights in environmental regulation and regard the reluctance of the regulators to adopt these techniques as an exception to the NPT. The history of antitrust is replete with restrictions-on price discrimination, vertical mergers, resale price maintenance, and so on-whose anticompetitive potential was first recognized by economists and more recently by judges and the enforcement agencies.

14. "Toward a More General Theory of Regulation." 
reduction in cartel rents. Second, those rents need not be spread to all consumers. Subgroups can organize (or be organized by the regulator) with the appropriate characteristics for efficiently reciprocating a regulatory benefit. Considerations like these led Peltzman to a general characterization of the politician's problem that is distinctly familiar to economists. Economic benefits to any group are reciprocated according to a technology of diminishing returns with the usual continuity properties. As a result, politicians normally hire the services of all groups. A similar general statement applies within groups. Given the usual constraints on discrimination, regulators will allocate benefits across consumer and producer groups so that total political utility is maximized.

This result-that all groups will share in the rents at the regulators' disposal-is as essentially empty as any similar result of constrained maximization analysis. It is the analytical equivalent of results such as "consumers buy food as well as clothing" or "firms hire capital as well as labor." And like these results, Peltzman's gives no guidance on expenditure shares, that is, whether the producers, the consumers, or neither group typically gets the lion's share of the rents. The interesting results in Peltzman come, as is usual in constrained maximization problems, from the comparative static analysis of the constraints on the utility function rather than from any worry over the detail of what is in that function.

In that formulation, the regulator wants to make everyone (with any marginal political weight) as happy as possible, but he is constrained by the demand and cost functions of the regulated industry. Peltzman then investigates the effect of changes in (or different types of) demand and cost conditions on the nature of the resulting equilibrium. Though some of the results are standard CT, or second-best welfare-economics fare (such as less elastic demand or supply functions imply higher prices), two predictions deserve special mention. They are the tendency toward systematic, cost-based cross subsidization and the tendency for regulation to offset the effect of market forces on the division of rents between producers and consumers.

A simple example helps illustrate these results. Suppose a regulated firm, X, sells to two customers, A and B. Suppose further that A and B have equal demands and equal political weight (that is, their utility enters the regulator's utility function in the same way), but that the marginal cost $(M C)$ is higher for serving A than for serving $\mathrm{B}$. Now recall the 
general result that $\mathrm{X}$ will not get maximum profits; for simplicity call this “'tax" on maximum profits, $T$, and assume it is fixed. Since X cares only about the size of $T$, not its distribution among $\mathrm{A}$ and $\mathrm{B}$, and since $\mathrm{A}$ and $\mathrm{B}$ are politically equal, the regulator has only one remaining task: to make the price $(P)$ to A and $\mathrm{B}\left(\boldsymbol{P}_{\mathrm{A}}\right.$ and $\left.\boldsymbol{P}_{\mathrm{B}}\right)$, and thereby A's and B's consumer surplus, as nearly equal as possible, given $T$. The result will be a lower $P_{\mathrm{A}} / M C_{\mathrm{A}}$ than $P_{\mathrm{B}} / M C_{\mathrm{B}}$. If $T$ is big enough to permit it, the regulator will completely ignore the fact that $M C_{\mathrm{A}} \neq M C_{\mathrm{B}}$ and set $\boldsymbol{P}_{\mathrm{A}}=$ $\boldsymbol{P}_{\mathrm{B}}$. While there are the inevitable complications and ambiguities, this tendency for the high-cost customer to get the low $P / M C$ is common. It rests on the lack of any general connection between the cost differences and the political importance of the two buyers. And it is a result that does not obtain in CT or NPT regulation or unregulated markets.

The regulator-as-buffer result can be illustrated by a cost or demand change that would leave prices unchanged in the absence of regulationsay a change in fixed cost. This change would, however, alter the distribution of rents between sellers and buyers. Since the regulator is seeking to maintain a politically optimum distribution, he will change prices to offset the distributional effect of the cost or demand change. Thus an increase in fixed cost does not come entirely out of $X$ 's hide, as in standard monopoly analysis; it gets translated into higher $\boldsymbol{P}_{\mathrm{A}}$ and $\boldsymbol{P}_{\mathrm{B}}$ to recover some of $X$ 's lost rents. Later I give examples of both resultsthe cost-based cross subsidization and the regulator as buffer-in the discussion of specific cases of regulatory change.

\section{Becker}

Results like these come from a view of regulation in which industry wealth (producer and consumer rents) is the prime political currency to be disposed of in ways that best suit the regulator. This view provides a link between the ET, with its emphasis on redistribution, and the NPT, with its emphasis on efficiency. That link has been most extensively developed by Gary Becker, first in his comment on Peltzman's paper and then in his 1983 article. ${ }^{15}$ His setup is similar to Peltzman's: groups organize to exert pressure on the political process to grant them benefits

15. Gary Becker, “Comment," Journal of Law and Economics, vol. 19 (August 1976), pp. 245-48, and "Theory of Competition among Pressure Groups." 
or exempt them from paying for others' benefits. And the equilibrium represents a balancing of marginal pressure exerted by winners and losers. Becker's central argument is that in a setup like this deadweight losses are a constraint on inefficient regulatory policies. The reason is simple: as the regulator moves output away from the efficient level, the deadweight loss increases at an increasing rate. (The marginal deadweight loss is the difference between the heights of the demand and the supply function, which gets bigger the further quantity is pushed from the efficient level.) Deadweight loss is nothing more than the winner's gain less the loser's loss from the regulation-induced change in output. These gains and losses are what motivate the competing pressures on the political process. So rising marginal deadweight loss must progressively enfeeble the winners relative to the losers. The pressure the winners can exert for each extra dollar's gain must overcome steadily rising pressure from the losers to escape the escalating losses.

Becker's formulation produces a political equilibrium with some deadweight loss. It does, however, suggest a bias against the unbounded deadweight losses implicit in the CT. Among the concrete manifestations of this bias is what Becker calls the "tyranny of the status quo." Most structurally competitive industries, for example, are not subject to price or entry regulation, even though the producers have Stiglerian organization and information cost advantages. But rising marginal deadweight loss can offset the producers' other advantages unless the demand and supply functions are sufficiently inelastic to attenuate it. The other side of this avoidance of inefficiency is a search for greater efficiency. Becker argues that the political process will be drawn toward efficient modes of redistribution in general and to efficiency-enhancing regulation in particular. The reason is simply that neither winners nor losers would rationally oppose changes that eliminated some deadweight loss. This is an important point for at least two reasons.

First, economists have a well-honed instinct for separating allocational from distributive issues. So there appears to be an obviously more "efficient" way of accomplishing the redistribution that the ET ascribes to regulation: why not directly pay off the winners without messing up a nice $P=M C$ equilibrium? In a world of competing pressure groups, however, no redistributive mechanism, not even the proverbial lumpsum tax, is without its deadweight cost. Payers and payees will incur costs to generate pressure and to alter their behavior so as to maximize 
the benefits or minimize the costs meted out by the political process. Given this situation, it is no longer obvious that all the costs associated with tax-transfer redistribution will be smaller than the costs of comparable redistribution through regulation. In fact, if regulatory redistribution survives, the presumption must be that it is the less costly mode. Otherwise both winners and losers would press for a change.

Second, market failure, the standby of the NPT, creates incentives for regulation. If regulation can reduce the resulting inefficiency, there will be more wealth available for distribution. This extra wealth can induce greater pressure for regulation from winners and can attenuate the opposition of losers. In contrast to the NPT, the ET says that the regulation will not maximize the extra wealth, because buyers and sellers are not in general equally well organized politically. But faced with a portfolio of potential areas to regulate, the political process will tend to be attracted to industries where it can increase wealth as well as to those where deadweight losses are small.

\section{Summary of ET Findings}

A useful way to summarize the foregoing discussion is to list some of the important characteristics of regulation that emerge from the literature on the economic theory of regulation.

-Compact, well-organized groups will tend to benefit more from regulation than broad, diffuse groups. This probably creates a bias in favor of producer groups, because they are usually well organized relative to all consumers. But the dominant coalition usually also includes subsets of consumers.

-Regulatory policy will seek to preserve a politically optimal distribution of rents across this coalition. Thus, over time, the policy will tend to offset changes in this optimal distribution arising from shifts in demand or cost conditions. At any one time, the price structure will crosssubsidize high-cost consumers from rents generated by prices to other groups.

-Because the political payoff to regulation arises from distributing wealth, the regulatory process is sensitive to deadweight losses. Policies that reduce the total wealth available for distribution will be avoided, because, other things being equal, they reduce the political payoff from regulation. 


\section{The Academic Effect of the ET}

While some of these features of the ET literature have received more attention than others, the literature as a whole has made its mark on academic analyses of regulation. Table 1 summarizes one measure of this impact, the number of citations to the three articles I have just summarized. To put this number in perspective, I have included citation counts for two recognized classics in the same general area-Coase's 1960 article on social cost and Averch and Johnson's 1962 article on rateof-return regulation. By now all three ET articles have passed AverchJohnson in the citation derby. The two mature ET articles-Stigler and Peltzman-have run considerably ahead of Averch-Johnson and below Coase in recent years. Stigler has been getting about two-thirds and Peltzman about one-half the citations accruing to Coase. Moreover, interest in this literature seems to be growing. Note the jump in the Stigler and Peltzman citations from 1980 on and the rapid growth in the Becker citations since publication. Becker's article is getting about twice the citations of its two predecessors at a comparable post-publication stage. Though citation counts are an obviously crude index, the data suggest that academics have been treating the ET as an important piece of intellectual capital that is not yet fully depreciated.

I leave an assessment of the reasons for this impact to others. Here I evaluate whether this academic success is somehow justified in light of recent real-world developments. Many of these involve deregulationthat is, exit from regulation. Exit is the logical and chronological successor to entry. So, before discussing the ET's success in coping with exit, I evaluate its utility as a theory of entry into regulation. I argue that as entry theories both the ET and its competitor, the NPT, have specific weaknesses that affect their ability to cope with deregulation.

\section{Entry in the Theory of Regulation}

Most of the development of the ET concerns the behavior of established regulatory bodies: whom they will favor and how and why their policies will change. But the question of why the body was established in the first place cannot be ignored. The ET's answer to that question is 
Table 1. Number of Citations to Selected Articles, 1972-86

\begin{tabular}{|c|c|c|c|c|c|}
\hline \multirow[b]{2}{*}{ Year } & \multicolumn{3}{|c|}{ Economic theory of regulation articles ${ }^{\mathrm{a}}$} & \multicolumn{2}{|c|}{ Other articles ${ }^{\mathrm{b}}$} \\
\hline & Stigler & Peltzman & Becker & Coase & $\begin{array}{l}\text { Averch } \\
\text { and } \\
\text { Johnson }\end{array}$ \\
\hline 1972 & $16^{\mathrm{c}}$ & $\ldots$ & $\ldots$ & 61 & 21 \\
\hline 1973 & 7 & $\ldots$ & $\ldots$ & 59 & 22 \\
\hline 1974 & 18 & $\ldots$ & $\ldots$ & 58 & 20 \\
\hline 1975 & 17 & $\ldots$ & $\ldots$ & 81 & 27 \\
\hline 1976 & 27 & $\ldots$ & $\ldots$ & 66 & 30 \\
\hline 1977 & 16 & $6^{\mathrm{c}}$ & .. & 53 & 30 \\
\hline 1978 & 29 & 11 & $\ldots$ & 56 & 19 \\
\hline 1979 & 28 & 19 & $\ldots$ & 74 & 32 \\
\hline 1980 & 48 & 33 & $\ldots$ & 90 & 25 \\
\hline 1981 & 42 & 31 & $\ldots$ & 84 & 14 \\
\hline 1982 & 53 & 46 & $\ldots$ & 102 & 28 \\
\hline 1983 & 60 & 34 & $\ldots$ & 100 & 29 \\
\hline 1984 & 67 & 48 & $12^{\mathrm{c}}$ & 86 & 21 \\
\hline 1985 & 79 & 62 & 23 & 88 & 13 \\
\hline 1986 & 77 & 70 & 31 & 93 & 26 \\
\hline \multicolumn{6}{|c|}{ Annual average } \\
\hline $1972-86$ & 38.9 & 36.0 & 22.0 & 76.7 & 23.8 \\
\hline $1980-86$ & 60.9 & 46.3 & 22.0 & 91.9 & 22.3 \\
\hline
\end{tabular}

Source: Social Science Citation Index.

a. George J. Stigler, "The Theory of Economic Regulation," Bell Journal of Economics and Management Science, vol. 2 (Spring 1971), pp. 3-21; Sam Peltzman, "Toward a More General Theory of Regulation," Journal of Law and Economics, vol. 19 (August 1976), pp. 211-40; and Gary Becker, "A Theory of Competition among Pressure Groups for Political Influence," Quarterly Journal of Economics, vol. 98 (August 1983), pp. 371-400.

b. Ronald H. Coase, "The Problem of Social Cost," Journal of Law and Economics, vol. 3 (October 1960), pp. 1-44; and Harvey Averch and Leland L. Johnson, "The Behavior of the Firm under Regulatory Constraint," American Economic Review, vol. 52 (December 1962), pp. 1052-69.

c. Includes previous (publication) year.

about what one would expect from a maximizing theory of institutional behavior: politicians seek politically rewarding fields to regulate and avoid or exit from the losers. The difficulty with the ET as an entry theory is precisely that it never gets much beyond this level of generality.

Consider Stigler's version. In some absolute sense, the lopsided advantages that producers have over consumers are essentially universal. This fact suggests that regulation which generates rents for producers should also be universal. To the non-Marxist, or anyone concerned with making distinctions, such a formulation obviously says too much. Accordingly, Stigler implicitly imposes a budget constraint on the entry problem. To find the prime candidates for regulation, he looks for industries where the producers' advantage is unusually large. Opera- 
tionally this means searching for a link between the probability that an industry is regulated and variables like the geographic concentration of sellers which are proxies for organization or information cost advantages of producers. Stigler has only limited success with this strategy, nor has it led to a literature with much stronger results. Given the lack of explicit attention to constraints on entry, one leaves Stigler's model with the nagging question of why minimum rate or entry regulation of structurally competitive industries is comparatively rare. ${ }^{16}$

Peltzman's version is hardly an improvement. Given its emphasis on the optimal allocation of wealth among potentially conflicting interests, almost anything that makes the wealth pool "large" or its allocation politically nonoptimal should induce regulatory entry. Thus both naturally competitive and naturally monopolistic industries ought to attract regulation (they are at a "corner" and hence farthest from the optimal rent distribution). Growth in demand, technological progress, inelastic supply and demand curves (all of which generate large or growing wealth), and unexpected disturbances in supply and demand (which upset the optimal wealth distribution) are all mentioned as conducive to regulation. This list is still reasonably compact, but it is unclear that the extra variables buy much more explanatory power. That is, Peltzman's model, like Stigler's, seems incapable of explaining why substantial and continual regulation of important structural or behavioral characteristics seems concentrated in a few industries.

In this respect, Becker's article marks an advance. In its full generality-efficiency in producing pressure for regulation generates regulation-Becker's formulation shares the infirmities of its two predecessors. But the specific emphasis on economic efficiency leads Becker to emphasize correction of market failure as an important motive for regulation. If market failure is comparatively rare, Becker's version of the ET gives some insight into the pattern of regulation. Consider a political decision on whether industries $\mathrm{A}_{i}, \mathrm{~A}_{2}, \ldots, \mathrm{A}_{n}$ or $\mathrm{B}$ should be

16. There are, of course, modes of intervention other than rate or entry regulation that, in principle, are within the purview of the ET. Such measures as tariffs, taxes, subsidies, and product standards have distributive implications that generate incentive for political pressure. On the broadest view, therefore, every industry is "regulated" to some degree. This view, however, still begs a question about magnitudes: a handful of structurally competitive industries seem singled out for unusually large departures from competitive equilibrium. 
regulated, where the $A_{i}$ are all structurally competitive and $B$ is ridden with market failure. The proregulation pressure group in each of the $\mathrm{A}_{i}$ is handicapped by the regulation-induced deadweight losses, and the group in B is helped by the potential efficiency gains. If regulation is not universal, B would, all else the same, end up as the only regulated industry.

Read this way, the ET comes close to merging with the NPT's entry story-entry occurs only to correct market failure. Shouldn't we then just invoke Occam's razor and prefer the NPT? The answer, given our present state of knowledge, is a resounding maybe. If there is an empirical basis for the NPT's continuing attraction for economists, it is probably its apparent success as an entry theory. Consider Hotelling's classic statement in 1938 of the natural monopoly version of the NPT. ${ }^{17}$ In this purely theoretical piece, railroads and utilities are presumed, without much evidence, to be the main real-world examples of natural monopoly. They also occupied most of the regulatory (including public ownership) effort when Hotelling wrote. This correspondence between the NPT and the real-world allocation of regulatory effort seems striking. Now consider the postwar expansion of regulation. In terms of the resources involved, the biggest single chunk is probably accounted for by environmental regulation, where the externalities aspect of the NPT scores another success. As for much of the impossible-to-catalogue remainder-health, safety, old-age security, and so on-the NPT becomes frayed at the edges. To be sure, a good economist needs no more than fifteen minutes' notice to produce a market failure to "explain" any of these interventions. But credulity is strained when the list of market failures grows at roughly the same rate as the number of regulatory agencies. And even in Hotelling's time the regulation of trucks and airlines, agriculture, labor markets, and many professions was already taxing the NPT's explanatory power. In sum, if the ET overpredicts the incidence of regulation, the NPT underpredicts it. If a case exists for favoring the NPT as a general entry model, it would be that underpredicting a comparatively rare phenomenon produces a smaller average error than overpredicting it.

17. Harold Hotelling, "The General Welfare in Relation to Problems of Taxation and of Railway and Utility Rates,' Econometrica, vol. 6 (July 1938), pp. 242-69. 


\section{Regulatory Change in Theory and Practice}

The topography of American regulation has changed considerably in the last two decades. Some types of regulation have grown or consolidated their position: regulation of the environment, product and workplace safety, the medical industry (such as prices and entry of hospitals), the disclosure of financial information, the operation of financial institutions (such as the de facto nationalization of distressed banks and savings and loan associations), and labor contracts (especially race and sex pay differentials). The avidity with which particular administrations pursue these areas may vary, but the strength of the governing institutions has grown or remained unchallenged. Here I focus on a historically more interesting change: the substantial reduction or elimination of the regulation of entry/exit or rates, or both, in a number of industries. These comprise surface and air transportation, long-distance telecommunications, securities brokerage, and bank deposits. In one important caseoil-maximum price regulation came and went within a decade. For nearly a century it had appeared that each new peacetime regulatory initiative was essentially permanent. That historical pattern was now decisively broken.

These deregulation initiatives are particularly interesting to economists. Had they been put to a vote of the American Economic Association membership, all the initiatives would have passed with large majorities. Probably not since the rise of free trade in the nineteenth century has so broad a professional consensus been so well reflected in policy. The reason for this consensus is economists' belief that deregulation enhances efficiency. This naturally raises a question about the current status of the NPT. Has it been resuscitated because of deregulation? Though the full answer requires evaluation of the alternative ET, deregulation hardly seems like a striking confirmation of the NPT. The main reason has to do with timing. The $\mathrm{P}$, or positive, part of the NPT implies two reasons for deregulation: (1) technological or demand changes eliminate the market failure, or (2) regulation is revealed to have been a mistake by the light of the $\mathrm{N}$, or normative, part of the theory. Most of the examples of deregulation would fit into the second category. The difficulty for the NPT is that these were recognizable as mistakes 
long before deregulation corrected them. The most obvious problems for the NPT are those cases not discussed here, because deregulation has not yet occurred. For example, the continued licensing of a myriad of professions, such as barbers and beauticians, looks like a continued mistake by the light of the theory. Of the cases I discuss, at least two, ceilings on bank deposit rates and minimum brokerage rates, were normative mistakes from the start, about forty years before deregulation. In transportation, the normative argument for truck regulation had also been dubious from the beginning (1935). As for rail and air transport, the normative case for at least some easing of regulatory constraints on competition goes back at least to the early 1960s. When the exit required by the theory takes twenty or forty years or has yet to occur, the theory can hardly be deemed powerful. Among the cases I discuss, the only one where deregulation seems to have followed reasonably promptly after the normative basis of the regulation became obsolete is longdistance telecommunications.

The relevant question is whether the ET looks any better than the NPT from today's vantage point. My overall answer is that it does, though the ET has its share of failures and unanswered questions. I should point out that the same question and roughly the same answer can be found in an article by Theodore Keeler. ${ }^{18}$ His analysis is more narrowly focused on transportation than mine, and it is couched in terms of a synthesis between the NPT and ET. So, though I place more emphasis on the differences between the two theories than he does, there is inevitable overlap. I begin this evaluation of the ET by first summarizing what the theory says about deregulation. Then in the following sections I proceed case by case to summarize the "facts" surrounding deregulation and show how these facts are or are not consistent with the ET explanation of deregulation. I then try to draw general conclusions about the state of the political economy of deregulation.

My discussion of the entry model implicit in the ET points to two general sources of pressure for deregulation: changes in the "politics" and changes in the "economics" of the regulated industries. Political change includes such things as shifts in the relative political power of contending groups and changes in the underlying organization and

18. Theodore E. Keeler, "Theories of Regulation and the Deregulation Movement," Public Choice, vol. 44, no. 1 (1984), pp. 103-45. 
information technologies. Anything that, for example, made it cheaper to organize or inform the broad mass of consumers about the adverse consequences of regulation in a structurally competitive industry would increase the political payoff to deregulation. Here I ignore these political factors, partly because economists have so far had limited success in pinning them down, but mainly because the more familiar terrain of the economic factors is sufficiently fertile. In the Peltzman and Becker versions of the ET, two kinds of economic change are conducive to deregulation: (1) the gap between the regulated equilibrium and the one plausibly characterizing deregulation of the industry narrows, so continued regulation becomes pointless, or (2) the wealth available for redistribution becomes too small to provide the requisite political payoff to regulation. ${ }^{19}$ These two forces can be related. For example, a lower demand for the regulated industry's product may bring the regulated price closer to marginal cost, and it will lower the potential producer rents from regulation. However, I argue that the second force-decreases in available wealth-is empirically more important.

To see how a reduction in available wealth can lead to deregulation, consider the simple case of a constant-cost industry that experiences increased input prices. That reduces the available sum of producer and consumer surplus. In Peltzman's analysis the first-order regulatory response is to distribute the loss across producers and consumers with a price increase less than the cost increase. But this reduces the producer rents that must pay the organizational and information costs that politically support regulation. If the cost increase is large enough, the producer rents may no longer be sufficient to generate the requisite political support for continued regulation. ${ }^{20}$ In Becker's framework the loss of rents reduces the pressure for continued regulation of this industry

19. The first type of change-convergence of the regulated and deregulated equilibriums-would also produce deregulation in the NPT. The difference between the two theories rests on how the convergence occurs and where the regulatory equilibrium is. In the NPT, convergence would occur because the source of market failure is removed by a change in technological or demand conditions. Then the market could be relied on to prevent a wedge between price and marginal cost. Since the ET equilibrium entails a regulated wedge between price and marginal cost, convergence occurs because the wedge that optimally allocates available rents differs trivially from the unregulated wedge.

20. The producers will continue to support regulation, because it promises some rents. But if the rents are too small to finance politically effective support, the political process will seek greener pastures. Producer requests for a free or even cheap lunch will not be honored. 
relative to other industries, and the higher price increases the counterpressure from consumers. Suppose further that the cost increase has in fact been induced by regulation. Then the dead weight losses emphasized by Becker become especially important. There is now not only attenuated support for continued regulation but also the potential for major gains in political utility from deregulation. These would come from the elimination of the cost increase attributable to regulation. For a structurally competitive industry, the lower costs would translate into higher producer and consumer surplus in the short run and higher consumer surplus in the long run, thus raising the possibility that the coalition pushing for deregulation would include some producers.

\section{Railroads}

Since the railroad industry was already mature and arguably overbuilt when the Interstate Commerce Act of 1887 was passed, the important features of regulation are control of rates and exit from the industry. The industry technology exhibits increasing returns to density and length of haul, which is also important in understanding the regulatory history.

The regulatory system that was to govern the industry until the late 1970s was not fully developed until the Transportation Act of 1920. That act, as implemented by the Interstate Commerce Commission, had the following results:

-A rate structure characterized by cross subsidies to the high-cost, light-density, and short-haul shippers from long-haul shippers on highdensity routes. As nonrail passenger modes developed and rail passenger densities fell, the cross subsidy was extended to rail passenger service.

-Commodity-based price discrimination was superimposed on this rate structure. Goods with a high value per ton and presumably lesselastic demands for freight (because transportation costs represented a smaller share of final product cost) tended to have the higher rates. Railroads could also collude on rate proposals.

-Exit control. Abandonment of freight and passenger service required ICC approval, and the ICC acted to slow the process-even to the point of discouraging applications-more than what the industry would have liked.

This structure is not, of course, wholly consistent with the earliest version of the ET, which mainly emphasized the producer interest. That 
interest is recognizable here only in the value-of-service rate structure (supplemented by collective ratemaking). But the basic structure of railroad regulation provides a good illustration of what is central to later versions of the ET-the spreading of rents to nonproducer groups. Producers got something-protection from competition and (at least temporarily) profitable price discrimination. Then these gains were partly shared with other groups through cross subsidies. Because these cross subsidies would otherwise induce exit from the industry, implementation of the scheme required restrictions on exit.

However, if this structure represented an equilibrium balance of forces in 1920, that equilibrium came under pressure almost immediately. Unregulated nonrail alternatives became increasingly viable as the highway and inland waterway networks spread. Trucks, in particular, began drawing some of the railroad's high-value, high-rate, primarily manufactured goods traffic. The resulting erosion of the rents that funded the political equilibrium was, of course, greatly exacerbated by the Great Depression. The first line of political defense was to bring the trucks under the regulatory tent in 1935.

The Motor Carrier Act of 1935 established minimum rate and entry controls on common-carrier trucks. If the first effect of this was to slow the erosion of railroad rents, subsequent developments rendered the regulatory system a mixed blessing for the railroads. The system now had two producer interests to contend with, and the trucking interest was soon to be aided by the unionization of the vast majority of commoncarrier truck drivers. Though the contribution of regulation is debatable, the fact is that the shift of traffic, particularly the high-margin manufactured goods, from rails to trucks continued over the ensuing decades. The corresponding shift in the political weights of the two ICC constituencies gradually weakened the railroads' stake in continued regulation. Empirically, their best response to the declining demand conditions they faced would have been exit. ${ }^{21}$ But maintenance of excess capacity was necessary to preserve the politically optimal system of cross subsidies. So, here, continued regulation could only hurt the railroads. Another margin of response to declining demand was price reductions. These sometimes elicited political opposition from the motor carriers, and this opposition now had to be paid heed. Thus important elements of the

21. Richard C. Levin, "Regulation, Barriers to Exit, and the Investment Behavior of Railroads,"' in Fromm, ed., Studies in Public Regulation, pp. 181-224. 
regulatory system undermined the railroad's battle to preserve their eroding rents.

Those rents would have been eroding without regulation, given the decline in demand and the long-lived, specialized nature of railroad capital. The plausible effect of regulation was to alter the time profile of the declining rents in a way that ultimately undercut the basis for the regulation. The elements of producer protection-the value-of-service rate structure, the constraints on intramodal competition-worked to make the initial level of the rents higher than otherwise. But the wealthspreading elements, manifested by the slowing of exit in the face of declining demand, and the need to serve the increasingly important producer interests of other modes, speeded the rate of decline of the rents. Over time the second effect came to predominate, so that the net effects of regulation on rail owners became unfavorable. ${ }^{22}$

In retrospect, the turn of the political tide toward deregulation can be traced to a spate of railroad bankruptcies in the early 1970 s. The bankrupt roads were located in the Northeast, which bore heavily the cross subsidy to short-haul and passenger traffic, and in the upper Midwest, where the cross subsidy to light-density traffic was important. These bankruptcies were a signal that the rents required to support the system created in 1920 were no longer available. The first political response was to nationalize the cross subsidies through Conrail and Amtrak. Given the railroads' continued secular decline, the choice facing Congress and the railroads was now clear: further nationalization or deregulation of exit and rates. The railroads chose deregulation and they essentially got it by $1980 .{ }^{23}$

22. Levin provided one measure of the magnitude of the unfavorable effect. He estimated that unrestricted abandonment would increase 1975 railroad profits by $\$ 1.4$ billion. This was about one-tenth of industry revenues at the time, or roughly the same fraction of revenue as total industry profits in the best postwar years. He also estimated that, even with these added profits, the industry's rate of return on assets would be less than 9 percent, a figure that is still plausibly lower than the (deregulated) industry's cost of capital. Thus, even after the response to unrestricted abandonment is complete, continued secular decline in the industry's capital stock can be expected. Ibid., p. 192.

23. This came in two stages, the Railroad Revitalization and Regulatory Reform (4R) Act of 1976 and the Staggers Rail Act of 1980. These eased constraints on mergers and abandonments and provided a wide band (a variable-cost) floor and (1.8 x variable cost) ceiling within which individual railroads could set rates to all but "captive" shippers without regulatory review. The net effect is to allow much more room for the railroads to abandon money-losing traffic and to compete with trucks and barges. 
This brief history fits the ET's deregulation scenario very well. The rents supporting the political equilibrium eroded, partly because of the incentives created by the value-of-service rate structure and partly because of the enforced provision of below-cost service. Support for the regulation eroded along with the rent. The organized producer interest ultimately favored and got deregulation. And the deregulation occurred not long after the economic and political forces turned decisively against regulation.

A major unanswered question in this story-which I return to but do not answer in my discussion of air transport-concerns labor rents. As an organized producer interest, it is plausible that unionized railroad workers shared in any rents generated by regulation. ${ }^{24}$ The magnitude of these rents and the degree, if any, to which they were eroded before or after deregulation remains uncertain. This uncertainty should not, however, obscure the basic message provided by the industry's financial difficulties: the old coalition of producers and consumers was no longer sustainable under the established regulatory framework.

\section{Trucking}

If rail deregulation is a victory for the ET, truck deregulation is a resounding defeat. In generating producer rents, trucking regulation was a signal and long-lasting success. Comparing wages of unionized workers in trucking with the wages of nonunionized trucking employees, Thomas Moore estimated a wage premium due to regulation exceeding 30 percent and showed that the premium was growing over time. From the analysis of transactions in operating rights, he was able to estimate that the total value of operating rights represented rents roughly equal to those of workers. Using more sophisticated statistical techniques than Moore, Nancy Rose basically confirmed the magnitude of the regulation-induced wage premium..$^{25}$

Where would the ET have us look for sources of pressure for regulatory change in this industry? The answers would include the following.

24. See Theodore E. Keeler, Railroads, Freight, and Public Policy (Brookings, 1983).

25. Thomas Gale Moore, "The Beneficiaries of Trucking Regulation,' Journal of Law and Economics, vol. 21 (October 1978), pp. 327-44; and Nancy L. Rose, "Labor Rent Sharing and Regulation: Evidence from the Trucking Industry," Journal of Political Economy, vol. 95 (December 1987), pp. 1146-78. 
-Growing labor rents. These may have been symptomatic of a drift away from the political equilibrium. The cost of that drift would include the accelerating deadweight losses emphasized by Becker.

-Dissipation of owner rents. The operating rights were not output quotas. On multifirm routes the minimum price regulation gave each firm an incentive to expand its market share, which led to cost-increasing service rivalry. Also, the entry control led to circuitous routing: a firm denied permission to enter the A-B market could get in if it bought an A-C and a C-B operating right, but then it had to move the freight through C. (Since these cost-increasing elements of the regulation raised the demand for labor, they would not be inconsistent with growing labor rents.)

-Deregulation of the railroads. This had the potential for lowering the present value of rents in trucking by more than the corresponding gain in total railroad surplus. The difference would be due to the inefficient traffic allocation engendered by rail deregulation when truck prices remained regulated: that is, rails could draw traffic when their marginal cost exceeded the truck cost by less than the regulated pricecost markup in trucking.

None of these possibilities can save the ET here. The reason is empirical rather than logical.

- The growing rents would suggest perhaps some easing of entry control to restore equilibrium. Instead, the regulatory rents have been entirely eliminated. The still-required operating rights are worthless, and according to Rose's estimate, the labor rent has vanished.

-According to Moore's comparison of the price effects of regulation with the observed rents, no more than one-fourth of the potential industry rent was being dissipated by such things as service rivalry and route circuity. And even if that estimate is not exactly right, the dissipation had to be far from complete, since operating rights of substantial value became worthless overnight because of deregulation.

-The importance of rail regulation as a source of rent for the regulated truckers has long been debated. And the excess capacity maintained by rail regulation worked to reduce rents in trucking. All this aside, however, there is a crude test that shows why rail deregulation cannot have been an important reason for truck deregulation. If it had been important, the trucking industry would have split politically. Those owners and Teamster locals facing especially close rail competition would at least have 
supported rate deregulation once rail deregulation was in the wind. That did not happen. The opposition of the American Trucking Association and the Teamsters to deregulation seems to have been monolithic and vigorous to the bitter end (too vigorous in the case of the president of the Teamsters, who was jailed for attempted bribery of the chairman of the Senate committee considering the deregulation bill).

Here then is an industry in which substantial and sustainable rents received the fullest measure of organized support from the beneficiaries. There is simply no way I know of to square the wholesale elimination of these rents by political action with any current version of the ET.

\section{Airlines}

The formal structure of airline regulation was essentially identical to that of trucking. Minimum rate and entry controls were combined with wide latitude for concerted industry action. But in terms of generating producer rents, airline regulation did not work as well as trucking regulation, and it worked conspicuously less well in the period just before deregulation. Table 2 provides some background. It shows the industry's operating cash flow (operating profits plus depreciation) as a percentage of revenues. In the parlance of the empirical industrial organization literature, it is an estimate of the industry's price-cost margin. I use cash flow rather than, say, accounting profits to allow for the possibility that rents may have been hidden in depreciation charges. ${ }^{26}$ Though any such accounting data are always to be treated gingerly, the story they tell is not fundamentally different from that found in more detailed analyses, such as those by Keeler, Douglas and Miller, and Jordan. ${ }^{27}$

These authors did not have the benefit of hindsight. However, if one takes the 1980s' data as typifying an unregulated equilibrium, the evidence suggests that regulation was generating some producer rents-

26. The airlines had the usual tax incentives to overdepreciate. These were enhanced by the CAB's use of rate-of-return targets as part of its rate regulation procedures.

27. Theodore E. Keeler, “'Airline Regulation and Market Performance,' Bell Journal of Economics and Management Science, vol. 3 (Autumn 1972), pp. 399-424; George W. Douglas and James C. Miller III, Economic Regulation of Domestic Air Transport: Theory and Policy (Brookings, 1974); and William A. Jordan, Airline Regulation in America: Effects and Imperfections (Johns Hopkins Press, 1980). 
Table 2. Airline Operating Cash Flow per Revenue Dollar, 1950-86

Cents per dollar

\begin{tabular}{cc||cc}
\hline Period & $\begin{array}{c}\text { Operating cash } \\
\text { flow/revenue }^{\mathrm{b}}\end{array}$ & Period & $\begin{array}{c}\text { Operating cash } \\
\text { flow/revenue }^{\mathrm{b}}\end{array}$ \\
\hline $1950-54$ & 23.2 & $1970-74$ & 13.3 \\
$1955-59$ & 18.2 & $1975-80$ & 9.8 \\
$1960-64$ & 14.9 & $1980-86$ & 7.1 \\
$1965-69$ & 17.7 & & \\
\hline
\end{tabular}

Sources: U.S. Bureau of the Census, Historical Statistics of the United States: Colonial Times to 1970, vol. 2 (Department of Commerce, 1975), p. 770; and Statistical Abstract of the United States, 1976, p. 612; 1986, p. 616; and 1988 , p. 592.

a. Operating cash flow $=$ operating profits (that is, before interest expenses and taxes) + depreciation.

b. Depreciation of ground assets is not reported before 1961. I estimated this at 4 percent of revenues for 1950 60 , the difference between the reported 1960 and 1961 ratios of depreciation to revenues. Data are for domestic operations.

maybe 10 cents per dollar of revenues-until the late 1960s. Then a process of erosion set in lasting up to the dawn of deregulation in 1978. In fact, erosion of potential rents seems to have had a longer history. Keeler estimated that around 1970 the average ratio of price to "competitive marginal cost" was about 1.5 for thirty routes. That translates into a price-cost margin of 33 percent. Note that the figures in table 2 , which make no allowance for capital costs, never approach that height. Why not, and why the decline in the decade preceding deregulation? The answer seems to lie in cost-increasing service rivalry induced by the structure of regulation. The industry's technology is characterized by economies (in terms of costs per quality-constant passenger mile) in distance and route density. The Civil Aeronautics Board fare structure imperfectly reflected the distance economy and ignored the density economy. Thus it contained elements of cost-based cross subsidizationfrom the low-cost, high-density long-haul markets to the low-density short-haul markets. But even many of the latter were potentially profitable.

Cost-increasing service rivalry, most notably from increased flight frequencies, had always been a source of rent erosion on nonmonopoly routes. It became increasingly important in the 1960s after the widespread introduction of jet-powered aircraft. This technology widened the scope for nonstop service in long-haul markets. The regulated fare structure made securing nonstop authority in such markets lucrative, especially in the high-density markets.

Throughout its history the CAB had assiduously resisted all pressure 
for entry by outsiders. But it was now faced with a shift in the distribution of wealth among its constituents that favored those with long-haul, nonstop authority. It responded in a manner consistent with Peltzman's wealth-spreading result. The poorer constituents were cut in on the lucrative routes. As a result, by the late 1960s most important routes were served by several carriers. Service rivalry thus grew more pervasive, so that wealth dissipation became the handmaiden of wealth spreading. One symptom of this phenomenon was the behavior of load factors. In the 1950-59 decade the average domestic load factor was 63 percent. In the next decade it was 53 percent. By the early 1970s (197073) this figure had fallen to 48 percent. By this time, it appeared that most of the industry rents had been dissipated by the quality competition. ${ }^{28}$

The $\mathrm{CAB}$ responded to these events with a celebrated domestic passenger fare investigation. This led to a number of administrative steps in the early $1970 \mathrm{~s}$, such as elimination of the distance cross subsidy, toward greater efficiency. In hindsight, these can be seen as the precursors of deregulation in 1978. As far as consistency with the ET is concerned, the story here was roughly the same as for the railroads, except that the dissipation of rents was more clearly related to the working of regulation. By the 1970s the regulation had rendered too many routes too competitive for minimum rates to generate the rents required to sustain support for regulation-a fact clearer in hindsight than it was when deregulation became live politically. Most of the industry opposed deregulation, but important fissures developed. For example, the largest airline (United), which had borne a heavy cost from the CAB's wealth-spreading policy on internal entry, supported deregulation.

As with railroads and trucks, an important question about the effect of regulation concerns labor rents. These played no important role in the academic literature on the subject. ${ }^{29} \mathrm{But}$ the air transport unions opposed deregulation, and deregulation has brought visible pressure on union wages. This casual evidence suggests that regulation may have been sustaining labor rents. Less casual, but very crude, evidence is not so clear. Table 3 shows the evolution of wages in the three transportation industries, relative to the average manufacturing wage, over the period

28. See, for example, Keeler, "Airline Regulation and Market Performance."

29. Keeler calculated his competitive marginal cost on the assumption that unregulated carriers would face the same labor costs as regulated firms. Ibid. 
Table 3. Wages in Transportation Relative to Those in Manufacturing, 1980, 1984

\begin{tabular}{lcrr}
\hline \multirow{1}{1}{ Industry } & Relative wage $(1975=100)^{\mathrm{a}}$ & $\begin{array}{c}\text { Percent } \\
\text { change, } \\
1980-84\end{array}$ \\
\cline { 2 - 4 } & 1980 & 1984 & 6 \\
Railroads & 109 & 116 & -9 \\
Trucking & 101 & 92 & 1 \\
Air transport & 108 & 109 &
\end{tabular}

Source: Bureau of the Census, Statistical Abstract of the United States, 1986, pp. 412, 414, 620.

a. For railroads, trucking, and all manufacturing, the wage is average hourly earnings; for air transport it is the Air Transport Association labor cost index.

spanning deregulation. From 1975 to 1980 wages in all three industries were rising at least as fast as wages elsewhere. But only in trucking was that tendency decisively broken in the early 1980s. In this respect, the crude data are consistent with what we already know from Rose's work about the demise of labor rents in trucking from deregulation. They are not consistent with a similarly pervasive erosion of labor rents due to deregulation of air and rail transport. ${ }^{30}$

Pending more systematic evidence on labor, it is best to be somewhat tentative about the details of the effects of airline regulation on producer rents. What can be said is that at least one side of the producer interestthe owners-had essentially lost their stake in continued regulation. And the deadweight losses of regulation had opened the possibility that they could now gain from deregulation. ${ }^{31}$

\section{Long-Distance Telecommunications}

Up to the 1960 s intercity telephone service was provided by a regulated monopoly, AT\&T, whose subsidiaries also provided most of the local service. The prevailing wisdom was that both types of service were natural monopolies, and though the regulatory authority was fragmented, both were regulated accordingly. The formal structure was maximum rate-of-return regulation. Since local and long-distance service shared common facilities, any statement about cross subsidies is tenuous. But

30. Card's analysis of airline mechanics' wages also finds little obvious impact of deregulation on this worker group. David Card, "The Impact of Deregulation on the Employment and Wages of Airline Mechanics," Industrial and Labor Relations Review, vol. 39 (July 1986), pp. 527-38.

31. That possibility appears to have been realized. According to Morrison and Winston, deregulation has produced gains of $\$ 2.5$ billion a year for the owners. Steven Morrison and Clifford Winston, The Economic Effects of Airline Deregulation (Brookings, 1986). 
two kinds of cross subsidy seemed to emerge from the regulation. Longdistance rates subsidized local service, and long-haul, high-density intercity service subsidized thin short-haul service. ${ }^{32}$ The latter is another example of cost-based cross subsidies, since the traditional long-distance technology is subject to substantial economies of density and distance. This rate structure combined with new technology to undermine the regulation.

Microwave technology developed rapidly after World War II. Unlike in the traditional technology, there are no important density economies in microwave technology. In addition, microwave costs came down over time, and by the 1960s they were below those of the traditional technology over a wide range of output. Thus comparatively small microwave systems were now cost-competitive with AT\&T, and the rents built into long-distance rates provided a further lure for actual competition. ${ }^{33}$ The first symptom of growing competition was the growth of private microwave systems, which carried signals for their owners. These private systems did not by themselves siphon off enough long-distance volume to threaten the continued viability of regulation. But the threat was obvious. Consider XYZ, Inc., which operated a private microwave system between its facilities in A and B. It was now possible for XYZ and even its employees and their friends in A to place a local call there to be transported by XYZ's microwave system to B, where another local call would carry it to anyone in $\mathrm{B}$. The total cost of this maneuver, including the two (subsidized) local calls, would be less than AT\&T's high long-distance rates. Thus the regulated rates and the new technology were providing an incentive for large users to build their own systems. They were also providing an incentive for these private systems to arbitrage the difference between AT\&T's rates and the private system's costs for third parties.

How far and how quickly such arbitrage would have spread in the absence of regulatory change is debatable. Until 1969 it was illegal for private microwave systems to offer long-distance service to the general public. Thus the relevant counterfactual (what would have occurred if

32. Leonard Waverman, "The Regulation of Intercity Telecommunications," in Almarin Phillips, ed., Promoting Competition in Regulated Markets (Brookings, 1975).

33. Waverman compares an estimated microwave cost function to AT\&T's cable costs. He finds that microwave average costs flatten at an output that is a trivial fraction of total output on typical high-density routes. He also finds that the minimum cost for microwave dominates the average cost of cable at any cable output level. Ibid. 
regulation had not changed) turns on the costs of getting around this legal restriction. Had these been suitably modest, a fairly rapid unraveling of the regulated rate structure becomes a credible part of the counterfactual. This scenario-a rapid dissipation of rents through competition from private networks-would then provide a basis for deregulation consistent with the ET.

This scenario never took place. And that fact, in my view, is not congenial to an ET-based explanation of the actual events. What happened was that the owner of a private microwave system, MCI, applied for permission to provide public long-distance service by interconnecting with the local networks. This permission was granted in 1969. That decision was the beginning of the end of regulation in long-distance telecommunications. There are now essentially no regulatory constraints on entry, and much of the proverbial cream has been skimmed from long-distance rates. Some formal rate regulation still exists, largely in the form of the rates charged the long-distance carriers for access to the now independent local networks.

The difficulty in viewing this history through the lens of the ET lies in the heavy weight one must give to the foresight of the regulators. One has to argue that they saw as imminent such a rapid erosion of the longdistance rents from the new technology that the present value of the political gains derivable from those rents had, in some sense, become negative by 1969 . This kind of argument does not sit well with the experience in airline and railroad deregulation, already reviewed, or in financial services, discussed below. In all those industries considerable actual rent dissipation preceded deregulation. Also, though we will never know the counterfactual time path of the long-distance telecommunication rents, we do know that the United States is still, twenty years after the crucial regulatory change, the main exception to a worldwide rule of entry restriction in this market. That fact at least suggests that U.S. regulators could have resisted new entry for some time after they permitted it. Accordingly, if one had to choose between the ET's explanation and the NPT's-that deregulation follows the demise of natural monopoly conditions-the latter is simpler and thus more appealing. ${ }^{34}$

34. The role of numbers, which Stigler emphasized and which I have so far ignored, may be more important here than in the other cases. Stigler argued that the politically dominant group would be neither too small to count politically nor too big to overcome 


\section{Stock Brokerage}

Though the history is somewhat murky, it appears that until twenty years ago a cartel of New York Stock Exchange (NYSE) members had been setting minimum brokerage rates since 1792. In the 1930s this cartel came within the ambit of the Securities and Exchange Commission (SEC). However, the SEC sanctioned minimum rates at least up to 1968. The interaction between the SEC and the NYSE cartel never acquired a formal institutional structure. But the rates bore the familiar imprint of cost-based cross subsidization: brokerage costs per share (or dollar) decrease as the size of the transaction increases, and these economies of size were incompletely translated into rates. The result was that profits on large transactions subsidized losses on small transactions. ${ }^{35}$

Gregg Jarrell has already invoked the ET in explaining the industry's transition to deregulation, and I can do little more than paraphrase him here. ${ }^{36}$ The precursor to deregulation was the rise of institutional trading in the 1960s. These large-block traders doubled their share of NYSE trading volume between 1960 and 1976, accounting for nearly half the volume at the latter date. Given the rate structure, this event increased the potential rent available to NYSE members. But that potential was not realized. The rent dissipation took many shapes, the most obvious being nonprice competition in the form of "free" ancillary services (research) provided to large institutional traders. Also, institutional traders began arranging trades off the NYSE floor, either through their own newly formed brokerage subsidiaries or through specialists that were not NYSE members. These leakages created a split within the cartel. The larger NYSE member firms, which wanted to compete for institutional business, were increasingly hobbled by the need to use inefficient methods to counteract the straight discounts offered by nonmembers. They ultimately supported rate deregulation (and, according to Jarrell, benefited from it).

free riding and rational ignorance. Depending on one's view AT\&T may have been too small (one firm) or too big ( 3 million stockholders) to dominate the compact group (large users and private system operators) that would benefit from deregulation of entry. See Stigler, "Theory of Economic Regulation."

35. See Gregg A. Jarrell, "Change at the Exchange: The Causes and Effects of Deregulation," Journal of Law and Economics, vol. 27 (October 1984), pp. 273-312.

36. Ibid. 
Formal deregulation of brokerage rates came through congressional action in 1975. But beginning in 1968, a series of regulatory changes pushed in the same direction-more competition and consequently lower rates on large transactions. So far, the brokerage story resembles the airline or railroad story: potential rents from regulation eroded to the point where the supporting coalition was undermined. There is, however, a twist in the story congenial to the ET. It lies in the growth of institutional trading, which touched off the forces leading to deregulation. The institutions had the attributes making for political success in Stigler's explanation-compact numbers with large per capita stakes. Jarrell, however, emphasized the purely economic aspects of the institutions' growth as embodied in Peltzman's version of the ET. The institutions were the relatively elastic demanders of NYSE brokerage services, especially after they began integrating vertically and arranging off-board trades. In Peltzman's multi-interest model, higher demand elasticities shift the equilibrium toward lower prices. So even if the consumers' political ability had not increased, the SEC would have faced pressure to weaken regulation.

\section{Bank Deposits}

The formal regulation of deposit rates is one of the series of regulatory reforms enacted in the wake of the widespread bank failures of the 1930s. But it took another thirty years for the regulation to have any substantial effects. The original regulation prohibited payment of interest on demand deposits and set a 2.5 percent maximum rate on time deposits in commercial banks. The latter was nonbinding for many institutions until the 1950s, and then was raised to 3 percent in 1957, the first move in a delicate balancing act that was to be played out in the ensuing years.

From the onset of regulation, ninety-day Treasury-bill yields never averaged over 4 percent in any year until 1966. In such a world the marginal effect of the interest ceilings was modest. They moved in the direction of providing some rents to the commercial banks and fostering the growth of savings and loan associations, whose rates were not then regulated. In this sense the regulation served some important organized interest groups-the commercial banks and the S\&Ls and their allies, the homebuilding industry. The banking rents were partly dissipated by various forms of nonprice and near-price competition, such as forgone 
service charges on demand deposits and competition in locational convenience (branching). But regulation of bank entry, state restrictions on branching, and prohibition of S\&L competition for demand deposits all acted to restrain the competitive rent dissipation.

This equilibrium could not withstand the dramatic increase in the level and volatility of interest rates that began in the late 1960s and became especially important in the inflation of the 1970s. The first symptom that the equilibrium was unraveling was the extension of maximum rates to the S\&Ls in 1966. As interest rates rose, the unregulated $S \& L s$ began drawing time deposits from the commercial banks. In 1966 the S\&Ls were allowed to pay only a fixed premium above the maximum rates for bank time deposits. This attempt to preserve the distribution of rents did not, however, work well. In the interest-rate environment of the time, fixed rate differentials exacerbated the volatility of the flow of funds between institutions.

Even more important cleavages were created by the unregulated capital markets' response to the regulation in this interest-rate environment. This response acquired a generic name-disintermediation. When market interest rates could quickly exceed the regulated rates by 500 basis points, depositors were motivated to look for close substitutes for deposits, and suppliers were encouraged to offer them. The first to benefit were the large depositors. Their major close substitute heretofore had been Treasury paper. Now, in the late 1960s and early 1970s, the commercial paper market grew rapidly and non-U.S. banks (joined by offshore subsidiaries of U.S. banks) began issuing dollar-denominated deposits, all at rates beyond the reach of the regulators. By 1970 it was clear that rate regulation on large time deposits was no longer viable, and these were deregulated. As monetary instability grew, the stage was set for new competition for the smaller depositors' business. Mutual funds arose that held the unregulated large-denomination deposits (and/ or T-bills, commercial paper, Eurodollar deposits, and so forth) and sold shares to the broad public. The average fee for this service is about 70 basis points per dollar of deposit, which was no longer enough to stifle their growth given the interest rates of the 1970s. When short-term rates rose into double digits, these funds came of age. From next to nothing in 1978 , their assets grew to more than $\$ 200$ billion by 1982 (or to roughly 15 percent of total time deposits of all financial institutions). An interesting wrinkle was that these funds typically allowed shares to be "sold" 
by a check drawn on the fund's bank account. The implications for the future of non-interest-bearing checking accounts were clear.

The rise of the money market funds made it clear that monetary instability and technology had rendered interest-rate regulation obsolete. It also tore apart what remained of the political coalition supporting the regulation. There had long been a large bank-small bank conflict about the regulation. On balance, the larger institutions were net losers because the regulation hindered their ability to compete against money market instruments for large time deposits. Now their "retail," or smaller deposit, base was being eroded by the growth of the money market funds. More important, the rate regulation was a threat to the future growth of the larger institutions. The same technology-telephones, computers, advertising, and so on-that permitted the funds to gather $\$ 200$ billion in a few years made it clear that the geographic balkanization of financial markets was ending. Many of the larger institutions saw their future in the retail market linked to geographic expansion. This meant ultimately attracting the customers of the smaller institutions as well as the relatively sophisticated and demonstrably mobile patrons of the money market funds. Much of the retail base of the smaller institutions consisted of customers who wanted locational convenience and who preferred an insured bank account to the new, unfamiliar money funds. They could be attracted, but not if the large banks had to pay the same rates as small banks. Accordingly, the large banks now openly supported deregulation.

In 1980 and 1982 Congress enacted legislation that, details aside, provided for phased deregulation of all deposit rates except business checking accounts. Given the history just outlined, the life of the latter anomaly may be brief. That history repeats a familiar scenario. A regulation once capable of generating rents was undermined by incentives-in this case to product innovation-created by the regulation that resulted in dissipation of the rents.

\section{Oil}

The history of oil-price regulation is brief and complex. I will ignore the complexities and, in the process, shove some arguably important 
interest groups into the background. Stripped to essentials, the facts are these. Maximum prices were set on domestically produced oil in the early 1970s. Price increases initiated by the Organization of Petroleum Export Countries (OPEC) in 1973 and 1979 pushed world prices substantially above the regulated domestic prices-roughly by a factor of two. The price ceilings were eliminated in 1980 , and a windfall profits tax was imposed in their place. This excise tax was a specified fraction of the difference between the transaction price and some stipulated base price for the oil. The tax was to be phased out beginning in 1988, but the base prices have exceeded market prices since 1985 . So the effective tax has been zero since then.

The way in which the rents captured from domestic oil producers were distributed is a matter of some controversy, which I will not join. It is sufficient to say that some were captured by intermediaries (refiners, wholesalers), some were captured by certain consumers, and some were dissipated in inefficiency induced by the detail of the regulation (most notably in the building of small, "tea-kettle," refineries). The weaseling here about consumers has to do with the uncertain effects of the regulation on product prices at those times-the majority-when there was no obvious queueing, and the uncertain benefits of the queueinducing prices to typical consumers. To simplify, then, I will henceforth call all the downstream users of oil and refined products "consumers."

These consumers lost their benefits in 1980 , but the industry was not deregulated. Instead, a new, arguably more efficient, method of collecting producer rents with a new beneficiary-the Treasury-replaced the old method. Accordingly, my focus here is not on the change in 1980, important as that may be in its own right, but on the larger question of why the producer rents were taxed in the first place.

The answer to that question, within the context of the ET, is fairly simple. It is to be found in the earlier history of regulation of the industry. Until the 1970s federal regulatory policy created producer rents. It sanctioned output quotas in the 1930s and enforced import quotas beginning in the 1950s. Both policy initiatives occurred in the wake of events (the Depression, the discovery of prolific fields in the Middle East) that reduced producer rents. Thus the producer interest had received its most active political support at times when rents were threatened. This is consistent with the aspect of the ET that emphasizes the role of regulation as a buffer against shifts in the distribution of 
wealth. Until OPEC increased prices in the 1970s, the important shifts were going against producers, and these were, as the theory predicts, offset by political action.

OPEC's actions, of course, resulted in a dramatic shift in the opposite direction. The rise in world oil prices generated a massive increase in the demand for domestically produced oil. In the absence of intervention, that would have generated a correspondingly large shift of wealth toward producers, thereby upsetting the politically optimum distribution of wealth. In these circumstances the theory predicts an offsetting tax on producer wealth, which is precisely what happened. The price ceilings and windfall profits tax would, in this theory, help to restore the politically optimum distribution as did the oil import quotas and production quotas in their day.

Thus the ET seems capable of telling a coherent story about regulatory policy both before and after the price increases. The about-face from generating to taxing rents did not represent some unintelligible loss of political power by the producers. (They were left with considerable rents from the OPEC price increases.) Instead, regulatory policy had to accommodate to a large outside shock, and the accommodation required just the sort of change in policy that occurred. The importance of this rent-buffering aspect of regulation is attested to by the fact that when price deregulation occurred, it was accompanied by an explicit tax on the resulting rents. The action of other countries in this period also tends to corroborate the importance of political rent-buffering. Those countries that had negligible domestic production (continental Europe, Japan), and consequently no domestic producer interest, allowed domestic prices to rise to world levels. Those that had substantial domestic production (Canada, Mexico), and would consequently, according to the ET, face the need to balance the interests of producing and consuming sectors, did just what the United States did. They kept domestic prices below world prices during the 1970s.

If the ET provides a unified explanation for oil regulation, it also suggests a corollary for the future. The current real price of oil remains about double the pre-1973 level. Any substantial decline to or below that level should produce pressure for revival of rent protection-through import quotas, tariffs, or other means. Any substantial increase, say to or above the 1973 or 1979 levels, would produce pressure for renewed taxation of the rents. 


\section{Summary}

The ET was born in a wave of enthusiasm for the notion that regulatory agencies are captured by producers. That notion left little room for deregulation: as long as an industry is viable producers can benefit from regulatory restraints on competition. The ET, however, has evolved away from those origins toward an emphasis on the coalitional aspects of politics. Here the need to balance pressures emanating from competing interests plays a central role. This formulation leaves much more room for deregulation. As long as deregulation benefits some part of the relevant coalition, it cannot be ruled out as a viable policy option. When the deregulation benefits become large relative to the associated losses, the probability that the option will be exercised rises. This situation is more likely to occur if the regulation itself has generated inefficiencies, so that shedding the inefficiency through deregulation provides a potential source of benefits.

Indeed, if there is a model of regulatory entry and exit implicit in the ET, a few simple notions can provide its outlines. Regulation occurs when there is a wide discrepancy between the political balance of pressures and the unregulated distribution of wealth. The regulation (of, say, price) then creates incentives for wealth dissipation (through, say, cost increases), which ultimately make restoration of the preregulation status quo more attractive than continuing regulation. In such a model deregulation is not the correction of some belatedly recognized policy error. It is the last stage in a process about which, in principle, all the actors could have had perfect foresight at the beginning. In practice, of course, there can be mistaken entry into regulation, but none of the industries I have discussed are obviously in this group. Airline regulation, for example, lasted four decades, and the others lasted longer. Few private sector enterprises would be deemed mistakes, even in hindsight, if they survived so long. The point here is that erosion and ultimate elimination of profits, either of the political or monetary kind, is not a reasonable criterion for evaluating the success of a venture. Some attention has to be paid to how durable the profits are and how quickly any requisite exit from the activity occurs. Indeed, if a model with "endogenous deregulation" proves a useful extension of the ET, it may 
help illuminate the selective character of entry into regulation. One reason for not regulating an industry would be the prospect that, for example, quality competition would erode rents so quickly that the upfront investment in political pressure required to implement regulation is not worthwhile.

Whether the deregulation is the predictable consequence of regulation or not, any explanation for deregulation derived from the ET has to look for some dissipation of the wealth upon which the political equilibrium in the theory is based. If there is only trivial wealth to redistribute, the ET finds no rationale for continued regulation.

I have examined some of the notable recent examples of deregulation to see how closely they fit the scenario implicit in the ET. Specifically, is there evidence of erosion of the wealth base on which the regulatory equilibrium was plausibly based? I also paid attention to magnitude and timing. Is the erosion plausibly large enough to suggest a crisis in which continued regulation would be unviable? Did the deregulation occur more or less promptly after the crisis?

The answers to these questions were mixed, but in the main followed the pattern implied by the ET. Two cases did not follow this pattern. Trucking was de facto deregulated when substantial rents were being earned by owners and workers who formed the heart of the relevant political coalition. Not only were the rents substantial, but there was no evidence of any serious erosion of them. Entry into long-distance telecommunications was deregulated after the technological threat to existing rents became clear but before substantial erosion took place. This is a less spectacular failure of the ET than trucking, but it has to be counted a failure nevertheless.

All the other cases follow more or less closely the pattern suggested by the ET. The railroads were deregulated after a long decline in demand that eroded the rents spread among producers and high-cost shippers. The precipitating crisis was the widespread bankruptcy and subsequent nationalization of important parts of the industry. Airline deregulation was preceded by a dissipation of regulatory rents because of service competition induced by the regulation. The dissipation followed promptly upon increased internal entry in the 1960s and was fairly complete by the 1970s when deregulation occurred. In the stock brokerage business, a sharp increase in institutional trading in the 1960 s created the crisis leading to deregulation in 1975. This shift in trading patterns provoked 
increased service rivalry and bypassing of the stock exchange, which dissipated rents and upset the intraindustry allocation of rents. In banking, the inflation of the 1970s bred the crisis leading to deregulation of deposit rates. The accompanying rise in nominal interest rates and in their variability allowed good substitutes for bank deposits to draw funds from the banks, and, as with the brokerage industry, exacerbated a divergence of interests within the industry. The last case I examined, petroleum, is somewhat special in that price deregulation was supplanted by an excise tax, which I interpreted as the last in a series of moves consistent with maintaining the optimum distribution of rents. Accordingly, I argued that obituaries for petroleum regulation may be premature.

Even though the ET can tell a coherent story about most of the examples of deregulation, it still cannot answer some important questions about them. Specifically, some of the examples raise questions about the design of institutions and their adaptability that have so far eluded the grasp of economists. Airline regulation is probably the best case in point. When it became clear in the early 1970s that service rivalry was dissipating rents, the $\mathrm{CAB}$ encouraged limited, voluntary output quotas. This tentative move was quickly abandoned. A more vigorous, possibly compulsory, system of quotas seems never to have been discussed, though it held the potential for preserving some rents and enhancing efficiency at the same time. The same ends could have been served earlier by a less relaxed policy on internal entry combined with more flexibility on interfirm transfers of operating rights than the $\mathrm{CAB}$ evinced. (Interfirm route transfers could be accomplished only through merger.) The then flourishing lightly regulated market in truck operating rights provided a potential role model. In short, obvious measures to stem the forces leading to deregulation seemed available but went unused.

Similar questions are raised by the history of railroad regulation. Here the government provided a flexible political response to the crisis of the 1970s. It nationalized the bankrupt railroads and passenger service and replaced the previous cross subsidies with substantial explicit subsidies. These can be viewed as a substitute for regulation in distributing wealth. For railroads, subsidies are in fact the mode of choice in most of the world for achieving roughly the same distributive goals as American railroad regulation did. But, except for passenger subsidies, the American rail subsidies were terminated by the end of the 1970s. If the ET succeeds in explaining the end of railroad regulation, it is obviously not 
sharp enough to explain why the alternative is deregulation here and subsidies in other countries.

These examples illustrate why the deregulation wave came as such a surprise to most economists. It was one plausible response to forces that called for regulatory change. But it was not, in many instances, the only plausible response. Indeed, in some cases, like those just cited, more or different regulation would have been an equally plausible response. To show the difficulty here, one need only consider an important contemporary regulatory problem-how to respond to the massive losses in the savings and loan industry. It is utterly implausible that the dissipation of upward of $\$ 50$ billion in public funds on unproductive investments and random transfers to impecunious borrowers is the low-cost method of serving this industry's political constituency. Accordingly, it requires only modest courage to predict that the current regulatory system will not survive much longer. Given our current state of knowledge, however, it requires a courage bordering on foolhardiness to predict the precise nature of the regulatory change that this particular crisis will breed. Policy options ranging from less regulation (such as reducing the scope of deposit insurance) to more regulation (such as increased capital requirements or restrictions on assets) would be consistent with resolving the crisis.

Twenty years ago economic theory faced the challenge of providing a basis for understanding the behavior of regulatory agencies. The ET was a modest step toward meeting that challenge. I have argued here that it also gives some insight into the forces that strain the institutional underpinnings of regulation. But so far a full analysis of the scope and form of these institutions remains unwritten. 


\section{Comments and Discussion}

Michael E. Levine: I agree that Peltzman's subject is an important area of exploration. In 1981 it occurred to me that the airline deregulation I had just finished designing and implementing at the Civil Aeronautics Board was not predicted either by my own earlier work or that of others. So I began to examine the implications of what I had just been through for the economic theory of regulation, which I, along with most scholars, took very seriously at the time. ${ }^{1}$

The strategy of my paper was, in effect, to say, "Well, the economic theory didn't predict airline deregulation or trucking deregulation or many of the other deregulations (communications, banking, securities) under way at the time, and therefore it was possible that the public interest theory was still alive." Perhaps public interest motives explained what Sam Peltzman has called regulatory exit. Since there was no evidence that the economic theory was dead (a great deal of regulation continued that could best be explained by that theory), I suggested in my paper that we needed some kind of meta-theory to reconcile regulation, which could be predicted by the economic theory, and deregulation, which seemed to be motivated by public interest considerations. We needed a theory that could predict when one might expect deregulation and when one might not. Or, more generally, we needed a theory to explain when one could expect government action oriented toward special interests as opposed to government action oriented toward mass interests, which at the time I conflated with the public interest. (I have rethought that since.)

We must now get the question right, as well as attempt an answer. I

1. Michael E. Levine, "Revisionism Revised? Airline Deregulation and the Public Interest," Law and Contemporary Problems, vol. 44 (Winter 1981), pp. 179-95. 
think the question is not, as Peltzman puts it, which of the two competing theories is the theory that explains regulation. One can find regulatory examples that seem perfectly consistent with the economic theory of regulation, as Peltzman does here, and find examples that do not seem consistent with that theory, as Peltzman does here, though I will question his classification.

One way to look at this paper is as an interesting attempt to challenge my 1981 assumption that the economic theory has been disproved and to prove it can be reconciled with the deregulation of the 1970s. Peltzman concludes that maybe it can and maybe it cannot. I tried to add up the score: it is hard to tell whether out of the seven cases he presents Peltzman won four or five or fewer. I admire his attempt to be fair, but I think he may have been too generous to the economic theory. I think it did less well than he claims, though I do believe in its continuing vitality as one model of regulatory origin and conduct.

In these comments I want to focus on two quite different points. First, I want to examine more closely the case I know most about, which is airlines, and suggest that Peltzman misinterprets the evidence, partly because he omits-deliberately in one case and inadvertently in some others-important benefits of airline regulation to special interest groups and partly because he does not, I think, characterize regulatory facts and institutions correctly. Airline regulation and deregulation are complex; Peltzman treats them rather cursorily. Second, when Peltzman decides to ignore the politics of the regulated industries in favor of the economics, I believe he turns away from the most promising avenue of exploration: attempting to reconcile the 1970s' deregulation with both the economic theory and the public interest theory.

Let me start with airline deregulation. I would argue there is no real evidence of systematically declining rents from airline deregulation. There is even perhaps some evidence of renewed increase in rents at the time deregulation began to occur. I base that argument on several points.

For one thing, accounting profits are very difficult to use as a measure of what rents were being accrued in the airline industry. We now recognize that the airline business had hidden assets in the form of leases on gates and historical leases on hangars, as I discovered when I tried to expand service and to repair New York Air's airplanes at the airport (LaGuardia) where that airline was based. Complex questions often arose about aircraft depreciation and valuations. And large unrealized 
gains and gains unrecognized by the accounting system were buried in airline balance sheets. For example, in 1979 or 1980 one airline that was having a particularly bad year recorded its only significant item of profit by writing off a DC-10 in an accident at Los Angeles. The gain from insurance payments compared with the book value of the aircraft was so large that it outweighed a considerable operating loss the airline had incurred that year. Any account of rents being taken from regulation must, I think, consider the accumulation of those kinds of assets and effects.

At the same time enormous information assets were being developed, what could loosely be called good will, but what I have recently argued are important effects that take advantage of information economies of scope and scale to produce market positions which turn out, in retrospect, to have been well protected from new-entrant competition. ${ }^{2}$ The value of that protection has proved to be considerable and was not reflected in the analysis Peltzman cites.

In addition, accumulated regulatory rents can be found in the certificate values that existed before deregulation and in the going-concern value of firms that have lost money consistently since deregulation, when certificate values dropped to zero. Because of positions they acquired and occupied under regulation, many airlines developed positive value in the face of continued operating losses. Pan Am's and Eastern's ability to continue in business while regulated and suffering large accounting losses on the operating side was paralleled after deregulation by their ability to continue to lose large sums of money under the discipline of market competition and to cover those losses by converting hidden assets to cash. This process has revealed the magnitude of the hidden assets built into those balance sheets: they were enormous, literally billions of dollars.

Furthermore, Peltzman consciously excludes labor rents. They were extremely significant, as I argued in a 1976 paper. $^{3}$

There were also very large cross-subsidy benefits built into the system, whether one is talking about the political advantages of funding nonstop

2. Michael E. Levine, "Airline Competition in Deregulated Markets: Theory, Firm, Strategy, and Public Policy," Yale Journal of Regulation, vol. 4 (Spring 1987), pp. 393494.

3. Michael E. Levine, "Financial Implications of Regulatory Change in the Airline Industry,'’ Southern California Law Review, vol. 49 (May 1976), pp. 645-64. 
service between Portland and New York (which could not sustain nonstop service, except in the particular conditions of regulation and jet service in the late 1960s and early 1970s) or about the political benefits of relatively equal fares on high-density and low-density routes. Those were all substantial benefits to groups that were being maintained by regulation.

Peltzman overlooked some of these rents, I think, partly because the traditional setting of airline regulation was different from the description given in his paper. The $\mathrm{CAB}$ treated the fare structure rather inconsistently over the history of regulation until the 1970 s, when I lost a court case based on the arbitrariness of the fare system. Before the DPFI (domestic passenger fare investigation) decisions of the early 1970s it did not systematically favor low-density over high-density routes. The fare structure was a product of old airmail regulation, and the amounts needed to make up the difference between operating losses and federal subsidies changed by increments over time as varying factors affected different routes and types of service.

Congressman John E. Moss and Ralph Nader brought the lawsuit that forced the board to explicitly consider the fare structure in the early 1970s. The board responded with the DPFI, which did institutionalize distance and density cross subsidies as well as rents built into the system that clearly affected the population of those who would be willing to continue to support regulation. In economic theory terms, the DPFI should have created a substantial constituency for continued support of regulation.

There was also really no change over the years in the government's willingness to encourage extra capacity in the industry. Industry overcapacity was a fact of life from early in the history of regulation. It is not important, really, whether it was or was not profitable for airlines; what is more important is that it did not change much over time. Probably from the early 1930s until deregulation, there were biases built into the system that did not change in magnitude.

Because the industry was cyclical, the forces producing overcapacity changed periodically through the years. Jets were introduced and were larger than the units they replaced. These introduced indivisibilities into the system, which exaggerated profit swings. The jets lowered load factors from 1958 to 1963 , but they had enormous service advantages that produced a surge of market growth with the prosperity of the middle 
and late 1960s. Load factors came back up and airlines acquired large earnings.

Since service competition was allowed, the airlines that were doing well in 1964-69 ordered wide-body planes. These were delivered just as the economy turned down. So airlines did not do well in the early 1970s. They were just beginning to do better when the oil shock hit, inducing the recession of 1973-74. But by the mid-1970s, when deregulation fever was at its highest, the airlines were beginning to do very well again. They were beginning to fill all those aircraft that had been ordered and that had been a millstone around their necks in the early part of the decade.

The jets and DPFI lowered average load factors. Contrary to what Peltzman says in his paper, the DPFI institutionalized (not eliminated) distance cross subsidy, but the degree to which this system was generating or not generating rent did not fundamentally change. Neither the government nor the industry cartel ever limited service competition and capacity competition, because such restrictions were prohibited by the Civil Aeronautics Act of 1938 and its successor, the Federal Aviation Act of 1958.

I think it is important to have some theoretical understanding of why prohibitions on control of capacity or service were built into a statute that everyone characterizes-including me, certainly, in my earlier work-as creating a cartel. If Congress was trying to design a cartel statute, that is an odd loophole to have left in.

The airline business was not institutionally almost identical to the trucking business, as the Peltzman paper suggests. The airlines were allowed much less explicit collusion. The CAB allowed airlines to ineffectively negotiate rates with other airlines through filings but did not allow them rate-bureau-type meetings on their own. And the board zealously enforced its version of the antitrust law. Many of us believed its version was not very procompetition, but the $\mathrm{CAB}$ did enforce it, often over airline protests, which the Interstate Commerce Commission certainly never did. Moreover, there were many fewer airlines than trucking firms. And airlines had consumer customers, whereas trucking had producer customers, a distinction that, I believe, is politically relevant.

Finally, producer and geographic opposition to deregulation was genuine and persistent. As a victim of that opposition, I can say it was personally vicious. At one point, in a strange political twist on Adam Smith, I was called a communist for favoring airline deregulation. 
Only United Airlines favored deregulation until the end when it became clear that the regulatory system as operated by Alfred Kahn and our colleagues was no longer providing anybody protection. Then people scrambled to get rid of the CAB because they didn't care for the uncertainty of leaving it around. But up to that point only United favored deregulation, and the opposition of the others was clearly not related to their profitability. Many of the opponents were money losers and had always been money losers, and others had made money through the regulated period.

Let me turn briefly to what I think are the analytical opportunities lost in this paper on the political side. Why some deregulations and not others fit the economic theory needs to be explained. As I said in my earlier paper, we need to look for a meta-theory. For that, we should probably look in the area Peltzman leaves unexplored by deliberate choice-the political economy of institutional change. We should look for answers using the recent literature that involves the modern economics of information and agency and examine not only coordination costs, which the traditional economic theory focuses on, but the costs to consumers and producers of monitoring the process and the complex relations among consumers, producers, legislators, their own committees, and agencies. If the results of theories that ignore these dimensions perplex us when we look at problems that are rich in the same dimensions, then it makes sense to look for answers among that complex web of relationships.

We need to deal in our models with the stubborn fact that inefficient regulatory structures persist over very long periods of time, contrary to what Gary Becker and Peltzman believe. But I do appreciate Peltzman's candor in noting that the "length of the run" matters in evaluating the theory. We must deal with institutions like agricultural regulation and occupational licensure. And we need to deal with the fact that CAB regulation was identified as inefficient as a theoretical matter in a book by Lucille Keyes in 1951, was revealed to be inefficient as an empirical matter by Richard Caves in 1962, and was shown to be inefficient as a comparative matter in a study I made in 1965 . Yet this process survived for more than forty years.

The ICC and its progeny lasted largely undisturbed from 1920 on. It was forty years in the making and sixty years in the ascendancy before it was dealt with in the Staggers Act and other revisions of the late 1970s and early 1980s. The CAB, as I have said, persisted for forty years. We 
need some theory to explain why these agencies all ran out of gas in one five-year period in the late 1970s.

Since the answers are more likely to be found in the modern political economy of agency and information, they will be heavily influenced by the peculiar economics of information, including its public-good character and economies of scope. Answers will also be found in the incentives and effects of policy entrepreneurs, "economists on white horses," politicans looking for issue labels that will position them clearly and effectively, and journalists looking for headlines that will capture viewers and readers. It is in these areas, I think, that we will begin someday to reconcile the economic theory and the public interest theory of regulation.

Roger G. Noll: Peltzman examines whether what he calls the economic theory of regulation accounts for the deregulation movement of the 1970 s and early 1980s. He sees the issue as a race between two contenders. The alternative he calls the normative-as-positive theory, which he uses as something of a straw man to be knocked down by positive economic analysis.

In my view a more apt name for the economic theory of regulation as described by Peltzman is the Chicago theory of government. In one sense his ET is narrower than the economic theory of politics, for it either ignores or only partly incorporates several other important contributions to the economics of political behavior. In another sense, it is broader than a theory of regulation, for most of the papers cited by Peltzman seek to explain much more than economic regulation.

The Chicago theory of government has three essential components. One is that changes in the opportunities for using the coercive power of the state to capture rents lead to institutional change. Initially, the theory focused on using regulation to increase the imperfection of markets in order to capture monopoly rents. But the theory is symmetric. Peltzman focuses on how the erosion of opportunities for monopoly rents can lead to deregulation.

A second component is that the costs of effective political organization differ among economic interests and so affect who is likely to be the winning bidder in the competition for the use of the coercive power of the state to generate rents. In particular, producer interests are more likely to have lower organization costs and hence to be favored by 
regulation. Peltzman acknowledges that Mancur Olson has made the biggest contribution to this line of argument; however, the Chicago theory, as I explain more fully later, has not incorporated very much of the theory of mobilization bias as developed by Olson and others. In fact, none of the early Chicago theory papers cites Olson except for George J. Stigler's classic article, and there the reference is only to one idea: that organizations already organized for other purposes (such as the provision of private goods to members) have a natural advantage in the political process. In general, Chicago theory models collapse the theory of mobilization bias into a variable called political power, which sometimes is a parameter and sometimes a function of the size and economic stake of an interest group.

The third main component of the Chicago theory, emphasized more by Gary Becker and Richard A. Posner than by Peltzman or Stigler, is the convergence of policy toward efficiency. That is to say, over the long run economic institutions, broadly defined to include aspects of the economic system that are controlled by government, tend to be efficiency enhancing. The reason, of course, is that inefficient institutions leave potential rents uncollected, so that in principle all parties to a policy can find a Pareto improving change to which they can agree. The limitation to the convergence to efficiency is simply the transactions cost of identifying the change and organizing to acquire it from government.

These three ideas about how policy changes constitute the theory that Peltzman tests against the normative-as-positive theory. My point of departure with Peltzman is to propose that other economic theories of government exist and ought to be considered. To avoid silly paternity debates about contemporary concepts of the economics of politics, I focus on economic arguments first stated before the publication of Stigler's 1971 article. My aim here is to describe some other economic theories of government and the predictions they make about the possible causes of deregulation.

\section{Three Alternative Economic Theories}

The first alternative theory I call Arrow I (after Kenneth J. Arrow), or social choice theory. It emphasizes the fundamental indeterminacy of democratic political systems. Originally the focus was on policy instability, a line of research that ultimately led to chaos theory, as 
promulgated by Linda Cohen, Steven Matthews, and Richard McKelvey. Chaos theory demonstrates that literally any policy outcome can be obtained from some form of agenda in a simple majority-rule democratic process; the primary lesson is that policies are inherently unstable and transitory.

The economists and political scientists who pursued this first wave of social choice theory were not satisfied with its implications about such remarkable instability, in part because in reality political systems are obviously not chaotic. Consequently, in the mid-1970s research in this area sought to determine why politics is stable. Today the leading explanation is the theory of structure-induced equilibrium, as originally proposed by Kenneth A. Shepsle and Barry Weingast. In essence, participants in the political process, recognizing its propensity for chaotic behavior and being risk averse (and hence valuing stability in its own right), construct constraints on policy change that increase the difficulty and cost of upsetting the status quo. Examples are bicameral legislatures, separation of powers between the legislative and executive branches of government, and the committee structure and rules of procedure in Congress.

Recently several scholars have applied this theory to study regulatory policy. One conclusion emerging from their research is that deregulation usually took place only where much of it could be accomplished without changing legislation; a regulatory agency could thus upset the status quo without obtaining any but the president's approval. Another conclusion is that sometimes the courts upset the status quo by interpreting statutes in ways not contemplated by Congress or the regulatory agency at the time the legislation was passed. In both circumstances subsequent legislative action was reactive: Congress lagged behind actual policy and was forced into action by the reality of the new status quo it had inherited from either the agency or the courts. ${ }^{1}$

Another recent offshoot of Arrow I is William Riker's theory of political entrepreneurship. A political entrepreneur is a person who

1. See John Ferejohn and Charles Shipan, "Congress and Telecommunications Policy Making," in Paula R. Newberg, ed., New Directions in Telecommunications Policy, vol. 1: Regulatory Policy (Duke University Press, forthcoming); and Matthew D. McCubbins, Roger G. Noll, and Barry R. Weingast, "Structure and Process; Politics and Policy: Administrative Arrangements and the Political Control of Agencies," Virginia Law Review, vol. 75 (March 1989), pp. 431-82. 
invents a way to undo structure-induced stability. He or she discovers how to take advantage of the fundamental instability of majority rule within the constraints imposed by the institutional arrangements designed to induce stability. In the regulatory sphere, Alfred E. Kahn and his colleagues at the Civil Aeronautics Board, and Darius Gaskins and friends at the Interstate Commerce Commission, subscribed to this theory. ${ }^{2}$ Essentially, these officials discovered how to accommodate a policy innovation within the proregulatory legal structure in which they operated. Their initial actions redefined the status quo and thereby changed the equilibrium legislative outcome in Congress, leading to legislative ratification of their initiatives after the fact.

The second alternative economic theory might be called Arrow II, because it is rooted in Arrow's early contributions to the economics of uncertainty in general equilibrium. Anthony Downs, however, was the first to relate these ideas to politics, so a fairer designation would be the Arrow-Downs theory. The basic conception is to apply state-preference theory and the theory of incomplete markets to the political sector. In particular, one might expect that some political contingencies are not freely traded in markets; the technical term is, I believe, bribery. Also, changes in information alter the choice of political strategies and outcomes.

Downs's line of analysis emphasized the relationship between voters and candidates for office; perhaps his most influential contribution was the theory of rational ignorance among voters. Because a single vote is both a weak indicator of preferences in multipolicy elections and an almost inconsequential act for outcomes, voters have essentially no incentive to devote effort or resources to becoming informed about the comparative merits of candidates. This concept has important implications for the role of interest groups in the political process, as argued initially by Downs and developed more thoroughly by Olson. Specifically, it introduces two means of political influence other than formal organizations: supplying free (and easy to digest, perhaps entertaining) information to voters that motivates their participation in the political process, and providing political saliency, a major national issue that commands attention and motivates action in the absence of political

2. Much of the descriptive material about how deregulation actually happened stresses the importance of specific iconoclasts within the reforming agencies. See, for example, Martha Derthick and Paul J. Quirk, The Politics of Deregulation (Brookings, 1985). 
organization. It also introduces another variable affecting the costs of organized participants-the costs of becoming sufficiently informed to take rational political action. So presumably organization costs will enter more heavily in areas of policy where information is voluminous and arcane than in areas where one can readily become informed.

Politicians can take advantage of salient issues by being the source of free information to voters on an important issue of the moment. An example from the early and middle 1970s was stagflation; the free information was inefficiency in regulated industries. Indeed a fairly common complaint was that "excessive regulation" was undermining business performance. Rationally ignorant voters, concerned about macroeconomic performance, could be expected to respond to this information by favoring economic deregulation, even though a fully informed analysis might conclude that economic regulation had only a trivial effect on national economic performance. Moreover, the simplicity of the point with respect to economic regulation-" "prices are too high"-may explain why regulatory reform was far more successful in that area than in many other areas where it was proposed, such as drug regulation, environmental regulation, and workplace safety and health regulation.

The third contending economic theory of regulation I call Leviathan. It is associated with the public choice scholars, such as James $\mathbf{M}$. Buchanan, William A. Niskanen, and Gordon Tullock. This theory says essentially that the coercive power of the state is monopolized by those in power and that they exploit it to their own benefit. Hence political actors-elected officials and bureaucrats-extract the rents from coercion, not the interest groups or other citizens affected by the policies. According to this view, for example, airline regulation would not be expected to benefit airlines, pilots, and flight attendants except incidentally, owing to a technical inability of government to extract all the rents. Instead the primary beneficiaries would be officials of the Civil Aeronautics Board, as a monopoly supplier of airline regulation, or the president and members of Congress, as monopoly providers of coercive power to the $\mathrm{CAB}$, or both.

The Leviathan theory predicts change in either of two circumstances. First, exogenous changes may cause political actors to be presented with new ways to enrich themselves. Second, citizens may gain control over government by forcing constitutional change, using instruments ranging from the initiative to revolution. Buchanan is an advocate of several 
constitutional changes to limit the size of government and the scope of its authority in economic policy. Obviously deregulation was not a result of constitutional change. Thus only the first reason holds: government officials enriched themselves through deregulation.

The discussion thus far has led to a more interesting horse race, for there are now five entrants instead of two. The next task is to see how each stacks up against the facts of the 1970s and 1980s. But before proceeding with that analysis, I went to explore more thoroughly the strengths and weaknesses of the Chicago entrant.

\section{Critique of the Chicago Theory}

Critics of the early Chicago theory claimed it bordered on tautology, in that (1) government actions surely redistribute wealth in some fashion, and (2) the relatively simple version of mobilization bias in the theory failed to predict who would win the bidding for a policy and seemed capable of explaining almost any regulatory outcome. Of course, the second point is much like the Arrow I conclusion of chaos, but the Chicago papers were written as though the equilibrium in regulation were unique and stable. Hence part of the criticism was that the theory assumed away the Arrow paradox.

Peltzman's important contribution was to provide a partial answer to both points, and in so doing to make the theory more complex. He does so by using the "can opener" assumption, a form of cheating ubiquitous in economic theorizing. Specifically, he takes a generalized function (here, '"power") to serve as the vehicle for making comparisons among claimants to policy rents in terms of their political influence. Power is, in turn, determined by organization costs. Positing the right power function gives the model an equilibrium and permits comparative statics on its parameters.

Peltzman's theoretical trick implicitly assumes away the Arrow paradox and the Arrow-Downs uncertainty problems. Basically it amounts to collapsing the policy area to one dimension, measured in dollars. By implication, the theory takes complete markets for granted and condenses all of politics to a single dimension in which median voter theorems can be invoked. Insofar as a model of elections and voter behavior underpins the Chicago theory, it is the unidimensional median voter equilibrium.

Becker and Stigler proposed another way to counteract criticism of 
the Chicago theory, by assuming that, deep down, everybody has the same preferences. If so, majority-rule voting does not need to overcome differences in ideal points in the policy area and has an equilibriumindeed, a unanimous equilibrium-at our collective bliss point. Rational ignorance is not a problem either, because social decisions can be delegated to a single informed expert whose self-interest coincides with society's interest.

Both means of avoiding the Arrow paradox and uncertainty problems leave one large issue unresolved, even if one accepts the core of the arguments. That issue is the decision about the distribution of wealth. Even if society can decide unanimously what should be produced, the problem of how to divide it has no equilibrium unless society adopts decision rules that predetermine the outcome.

Becker's recent work illustrates the preceding argument quite elegantly. Becker assumes that a differential incidence of transactions costs among citizens simultaneously determines political power and solves the divide-the-pie problem. But that requires also assuming something that in principle, as a theoretical matter, is false, namely that the allocation of relative power (for example, voting strength) can solve the impossibility theorem problem without creating a dictator. Becker shows that his assumption allows society to approach an efficient equilibrium, limited by the transactions cost of policy change.

What Becker's work demonstrates, beyond the kind of assumptions necessary to derive his conclusions, is the observational equivalence of the Chicago theory of government and the normative-as-positive theory. If the powerful need to create inefficiency to collect their rents, they ought to be able to orchestrate a mutually beneficial transaction with the unpowerful, essentially going public with their power. The constraint on such behavior is the transactions cost of selling out. As regards deregulation, the ultimate result should be greater efficiency, with at least as much wealth in the hands of the former beneficiaries as there was under regulation. The act of deregulation would allow an exogenous, unpredicted change that lowered the transactions costs or increased the potential efficiency gains of selling out.

Peltzman tends to emphasize only one of the possible paths to deregulation that is consistent with the Chicago theory. He focuses on exogenous changes that made maintaining the cost of the regulatory system unattractive. In essence, he argues that industries lost the rents 
accruing from regulation for one of two reasons. Either the costs of keeping other powerful interests in the supporting coalition became too great, or changes in the industry's costs and demand made the total amount of rent that could be extracted lower than the costs of maintaining the regulatory system. I will not comment on the cases he describes except to point out that his discussion leaves several unsolved puzzles.

-If railroad deregulation came because the costs of keeping trucks, small towns, and passengers in the coalition began to exceed the rents accruing to the railroads, why did regulation last so long? Before the railroad bankruptcies of the 1970s the industry suffered two decades of losses. If economic scholars figured out that railroads were the longterm net losers from regulation fifteen years before deregulation began, cannot we invoke rational expectations to postulate deregulation at least that early, if not earlier? Moreover, in the other cases of economic deregulation in transportation, the bankruptcies tended to follow deregulation, not precede it. Why were railroads different?

-Although the timing issue is also important in telecommunications, two other issues stand out. First, deregulation took place when AT\&T's rents from regulation-and the subsidy for rural telephone servicewere growing, not decreasing. This coalition was profiting handsomely, not suffering declining fortunes as the railroad industry was. Obviously the Chicago theory should not predict deregulation in two circumstances: when rents are growing and when rents are declining. Second, telecommunications deregulation did not occur in the states-at least, not yet. Should not at least the large states, which are microcosms of the national political economy, respond more or less in the same way as the federal government? And if Chicago theory predicts they will, why is the process so slow?

-Why did the deregulation of stock brokerage occur roughly simultaneously with the regulation of futures trading? The former is explained by a rising elasticity of demand for brokerage services. Is it plausible to believe that exactly the opposite shift in demand elasticity was taking place in another type of brokerage?

Peltzman is disarmingly critical of the Chicago theory's ability to explain some cases of deregulation. Yet, if anything, he leaves still other loose ends like those mentioned above. But these are insufficient data to call the horse race. How do the other theories compare in their explanatory power? 


\section{Evaluation of the Several Economic Theories}

Leviathan predicts that the rents went to the government. I think this idea can be laughed off, though Michael Levine's postregulatory career gives me pause. Nevertheless, one can safely dismiss the idea that the decline in rents accruing to the airline industry and its employees was not transferred to Michael E. Levine, Alfred E. Kahn, Elizabeth E. Bailey, Jimmy Carter, and Edward M. Kennedy. It does not stand to reason that the $\mathrm{CAB}$ maximized its profits by putting itself out of business. Thus the Chicago theory beats Leviathan by many lengths.

Arrow I argues that policy change is random and cyclic and does not require underlying changes in its prospective benefits and costs. But in the later versions that invoke structure-induced equilibrium, it also predicts that policy change will be infrequent-and slow to respond to exogenous changes that might occur in its underlying economics. The emphasis is on entrepreneurs who discover ways to upset an old equilibrium to their own political advantage. Stephen Breyer tells us that Edward Kennedy played this role in the airline case; later Kennedy failed in his attempt to play the same role in reforming drug regulation, even though the potential efficiency benefits there seem to be comparable in magnitude. Presumably the Chicago distinction between the two cases would be that airline interests, but not drug interests, had lost a stake in maintaining regulation. But the counterpart to "service competition" in airlines is the dramatic increase in the cost of drug research and development brought about by the 1962 amendments to the statutes governing drug regulation. Is the Chicago view plausible? Or is this an example of unpredictability: Edward Kennedy and Alfred Kahn proved to be a more effective entrepreneurial team than Edward Kennedy and Donald Kennedy, then the commissioner of the Food and Drug Administration. Certainly a valuable exercise for the interested student is to examine the failures of reform as well as the successes and to check out which explanation seems to work in both instances.

Finally, the Arrow-Downs-Olson school of imperfect information and mobilization needs to be examined. It comports with one puzzling fact: in the 1970 s and 1980 s several political candidates did link regulation with the overall performance of the economy, causing the issue to become sufficiently visible for several economists to respond by esti- 
mating how much of the problems of rising inflation and declining productivity could be attributed to regulation. Even the Business Roundtable weighed in, financing an expensive study to document these costs. Now why political actors attached plausibility to the argument that regulatory reform was an effective way to "whip inflation now" remains something of a mystery, but the kind of mystery that fits nicely with the branch of the economic theory of politics that emphasizes imperfect information. Moreover, the steam seems to have run out of the regulatory reform movement roughly coincidentally with the end of the stagflation period, late in the first half of the Reagan administration. Our interested student could spend profitable hours examining this explanation in more detail too.

The various economic theories of deregulation also make different predictions about the future. As I read it, the Chicago theory predicts movement toward marketlike solutions to the problems of environmental regulation, no reversal in economic deregulation, and state deregulation in areas where the federal government has already deregulated. Arrow I would not predict that any of these changes are more likely than any other. But under that theory, some reregulation will happen eventually, when some political entrepreneur figures out how to disrupt the existing state of policy for his or her own selfish ends. Arrow-Downs might predict reregulation as the salient national issue of sagging economic performance wanes, and so interest group politics regains its former significance in this domain of policy.

In my estimate the research is still inconclusive as to the relative merits of the various economic approaches to politics. The main inference to be drawn from my arguments is that all the approaches have something to contribute.

The Chicago theory has brought out the importance of the magnitude and distribution of the economic outcomes in explaining political change and, even more significant, has shown that political actors have more rents to distribute if they can arrange for an industry to operate efficiently. In the 1960 s and 1970 s economists probably overreacted to the waste that their research uncovered in virtually all areas of regulatory policies. As a result, they underestimated the power of economic efficiency arguments. The relation between the Chicago theory and the normativeas-positive theory is actually its strength, not its weakness, even if, as I believe, the connection may lead to Panglossian conclusions. 
The weakness of the Chicago theory is that it has not yet adequately taken into account the important lessons from Arrow I and ArrowDowns. Arrow I recognizes that institutional arrangements matter, for they lend stability and probably define the direction of feasible policy changes that might upset the preceding coalition. Arrow-Downs emphasizes the role of informational imperfections and the significance of incomplete political markets. The general theory of regulation that will be taught in the year 2100 will be an amalgam of these major ideas of Chicago, Arrow I, and Arrow-Downs.

\section{General Discussion}

The paper left many participants disappointed that a "meta-theory" has not emerged which can adequately explain when, and in what sectors, regulation is put into place and when and where it is dismantled. Consequently, participants defended a variety of eclectic or special case theories and offered various macroeconomic or economic disturbance explanations for the deregulation movement of the 1970s. Nancy Rose suggested that regulatory action takes place when there are substantial disruptions in the national economy. Many of the regulations that have recently been dismantled had their origins during the Depression and accompanying economic disruptions of the 1930s, she noted. Likewise, the industries that have recently been deregulated were in many instances industries that were severely affected by two major disruptive economic events of the 1970s: the surge in oil prices (airlines, trucking, natural gas, petroleum, and electric utilities) and the increase in volatility and levels of interest rates (banking and financial markets).

Robert Hall agreed, noting that "depression and war give us high taxes and regulation," whose burdens must then be worked off gradually over time. He observed that the recent period of deregulation preceded only slightly the large tax cuts of 1981, and suggested that the two events represented the final working off of the consequences of the Depression and World War II. Paul Joskow commented that economic disruptions often change the distribution of political power and create opportunities for public policy entrepreneurs to rearrange things to their advantage. He favors a theoretical approach that considers the interactions among economic dislocations of many kinds and integrates aspects of the 
economic theory of regulation with the other theories. In the case of airlines and trucks, he feels the entrepreneurial influence of Alfred Kahn and Elizabeth Bailey cannot be overstated. They and the other regulators had a policy agenda and used the administrative process, and the lags in the administrative process, to their advantage to accomplish certain changes. The process gave them a "window of time, perhaps a year when the public had a chance to see what some of the benefits of deregulation would be to them,' Joskow observed. This enabled them to identify a constituency for their proposed reforms, which made it more likely that the reforms would be ratified by legislation and the courts.

Alfred Kahn agreed that what he called the " demonstration effect" is important. He suggested that changes in the economic conditions of the industry, together with a macroeconomic environment of stagflation, set up conditions for deregulation in the airlines, where there were weak unions and most of the rents had already been dissipated. Deregulation in trucking then followed partly because the lessons learned from airline deregulation were transferred to trucking by the same political coalition, consisting of "[Edward] Kennedy, Ralph Nader, the Consumer Federation of America, Common Cause, the National Association of Manufacturers, and the National Federation of Independent Small Businesses."

William Nordhaus also stressed political factors, arguing that the bunching of regulation or deregulation movements across different sectors of the economy within short periods of time suggests that the ideology of the policymakers in power is an important influence. But that is tempered by the efficiency considerations that operate if the efficiency losses from political action get too large relative to the rents being redistributed. That explains why wartime price controls and allocation mechanisms are always quickly dismantled, he said.

Robert Crandall noted that an overall political or economic theory of regulation must be able to explain why regulation was expanding at such a rapid rate in areas like health, safety, and environmental regulation at the same time that regulatory constraints were being relaxed in other areas. And it should also be able to explain international anomalies, such as the fact that many other countries still do not allow private microwave businesses to compete with the primary providers of long-distance telecommunications service. 